\title{
ANTI-DOPING AGENCY - KNOWLEDGE, HUMAN RESOURCES, INNOVATIONS IN THE STRUGGLE FOR PURE NATIONAL SPORTS
}

\section{AGENCIA DE ANTIDOPAJE - CONOCIMIENTOS, CUADROS, INNOVACIONES EN LA LUCHA POR LE DEPORTE NACIONAL LIMPIO}

\author{
Nenad Dikić \\ Faculty of Physical Culture and Management in Sport, University Singidunum, Belgrade, Serbia, and Anti-doping Agency \\ of the Republic of Serbia, Belgrade, Serbia
}

\begin{abstract}
Anti-Doping Agency of the Republic of Serbia (ADAS) was founded by the Law on Prevention of Doping in Sports in 2005, and started operating on January 1, 2006. The fight against doping in Serbia is fundamentally associated with the adoption of the Law on Prevention of Doping in Sports in 2005 and 2014. Presently, ADAS has 71 doping control officers, including 8 animal doping control officers. The ADAS doping control officers have been trained for carrying out doping controls in national, but also in great international competitions. Since its foundation until present, 7821 doping controls have been carried out, 67 positive doping cases have been detected in 29 sports in the country, while 12 positive doping cases have been detected by the international associations. In addition, 4 other violations of anti-doping rules have been also recorded. Since its foundation until the end of 2017,226 TUEs were approved, but it is even more important that the awareness of sports professionals, especially team doctors, has been gradually developed through the training courses organized by ADAS once a week on average. Over just one decade, AntiDoping Agency of the Republic of Serbia has become one of the most respected sports institutions, and through its knowledge and work performance it has become a partner not only of the national sports organizations, but also of a large number of sports organizations all over the world.
\end{abstract}

Key words: ANTI-DOPING/ NATIONAL AGENCY/ INNOVATIONS / SERBIA

\begin{abstract}
EXTRACTO
La agencia de antidopaje de la República de Serbia (AADS) está fundada por la Ley de impedimento de dopaje en el deporte el año 2005, y empezó a trabajar el 1 de enero del año 2006. La esencia de la lucha contra el dopaje en Serbia está relacionada con la aprobación de la Ley de impedimento de dopaje en el deporte el año 2005 y el 2014. Momentáneamente, la AADS tiene los 71 controladores de dopaje, incluyendo también los 8 controladores para los animales. Los controladores de dopaje de la AADS son entrenados para hacer controles en las competencias nacionales, pero también en las grandes competencias internacionales. Desde su fundación hasta el momento se ha realizado 7821 control de dopaje, se han descubierto 67 casos positivos de dopaje en 29 deportes dentro del país, mientras que, por parte de las federaciones internacionales se han descubierto 12 casos positivos de dopaje. Además, se han notado 4 violaciones más de las normas de antidopaje. Desde su fundación hasta finales del año 2017 se han aprobado 226 AUT, pero todavía más importante es que la consciencia de los trabajadores deportivos, sobre todo de los médicos de equipos, se ha desarrollado paulatinamente a través de la educación que la AADS realiza en promedio una vez a la semana. La Agencia de Antidopaje de la República de Serbia durante solo una década se convirtió en una de las instituciones más respetadas en el deporte que con su conocimiento y trabajo llegó a ser no solo el socio de las organizaciones deportivas en el país, sino también de un gran número de organizaciones en el mundo.
\end{abstract}

Palabras claves: ANTIDOPAJE/ AGENCIA NACIONAL / INNOVACIONES/ SERBIA 


\section{INTRODUCTION}

The Anti-Doping Agency of the Republic of Serbia (ADAS) was established by the Law on the Prevention of Doping in Sport adopted in 2005 by the Parliament of the Republic of Serbia. It began its work on January $1^{\text {st }}, 2006$, and thus, under new legal and organizational conditions, continued the fight against doping in sport that was run by the Sports Medicine Association of Serbia in the period 2003-2005. Since its founding, ADAS has planned its activities in three directions, with the aim of realizing the mission and its program activities, such as: the implementation of doping control, education and research.

The fight against doping in Serbia is a decadelong problem and a challenge that enters into its most intensive phase by adopting the Law on the Prevention of Doping in Sports (2005 and 2014). The fight against the efforts of Serbia's sport and society in the fight against doping in sport is in international professional and political conventions confirmed by the decisions of the Parliament of the Republic of Serbia and legally formulated through the Law on the Confirmation of the International Anti-Doping Convention 2009 and the Sports Law from 2011 and 2016. By adopting the Convention and enacting laws, the Republic of Serbia has expressed a value orientation towards the problems and challenges of modern sports. In doing so, it fulfilled its international obligations in the field of combating doping in sport and ranked among the countries that formally legally accepted the World Anti-Doping Code, enabling individuals and teams from Serbia to participate in all international competitions, i.e. the national sports federations to apply and be chosen for organizing them. According to the statement of the World Anti-Doping Agency, ADAS has completely harmonized its work with the latest amendments to the World Anti-Doping Code, which have been in force since $1^{\text {st }}$ January 2015.
In addition to meeting the conclusions of international sports, health, humanitarian and political organizations, ADAS is characterized by continuous, intensive work on the construction of organizational, technological and innovative steps that are now being fulfilled under the leadership of a director and board of 15 members, with the work of the Anti-Doping Committee of 9 members, TUE committee of 3 members, doping control committees with 71 doping controllers, including 8 animal controllers. The quality and high standard in the realization of the ADAS mission is verified by contracts with international federations for basketball (FIBA Europe) and mountaineering (UIAA), as well as many other international federations. Since the establishment of ADAS, doping control has been done in over 100 international competitions, including controls at the largest multisport competitions hosted by Serbia, such as the European Youth Olympic Festival (EYOF - 2007) and the Universiade (2009).

Accordingly, the problem of this paper is related to the anti-doping policy implemented in the Republic of Serbia, i.e. the place and role of the national anti-doping agency in the formation and operation of such a national body, the adoption of codes and legislation, the struggle to reduce the traffic of prohibited substances on the territory of Serbia, on training and improvement of doping controllers, educational programs with athletes, coaches, sports organizations, as well as citizens, pronouncing sanctions and monitoring their realization, cooperation with sports organizations of all levels, cooperation with accredited antidoping laboratories... The method applied in the drafting of this work can be defined as methodologically complex, because the deduction is used while until the problem goes through non-experimental methods of observation, reflection and analysis of the case. 


\section{ANTI-DOPING AGENCY OF SERBIA - A DECADE OF CHALLENGES AND DEVELOPMENT}

\section{A Period of Development through Determination of Anti-Doping Violations}

In the past 12 years, the Anti-Doping Agency of Serbia has made a significant progress in the number of doping controls performed. Since its establishment until today, 7821 doping controls have been made at domestic and international competitions, starting in 2006, when 31 doping controls were completed, and by 2017, which ended with 1048 doping controls completed (Table 1).

Table 1. Number of doping controls by years, number of ADAS and IF doping positive cases and other violations of anti-doping rules

\begin{tabular}{|c|c|c|c|c|c|}
\hline Years & $\begin{array}{c}\text { The total number } \\
\text { of tested athletes by } \\
\text { years }\end{array}$ & $\begin{array}{l}\text { The number of } \\
\text { doping positive } \\
\text { athletes ADAS }\end{array}$ & $\begin{array}{l}\text { The number of } \\
\text { doping positive } \\
\text { athletes IF }\end{array}$ & $\begin{array}{l}\text { Other violations of } \\
\text { anti-doping rules }\end{array}$ & $\begin{array}{l}\text { Total number of } \\
\text { violations of anti- } \\
\text { doping rules }\end{array}$ \\
\hline 2006 & 31 & 1 & 0 & 0 & 1 \\
\hline 2007 & 347 & 0 & 0 & 0 & 0 \\
\hline 2008 & 494 & 7 & 1 & 1 & 9 \\
\hline 2009 & 767 & 2 & 1 & 1 & 4 \\
\hline 2010 & 717 & 17 & 3 & 1 & 21 \\
\hline 2011 & 1021 & 11 & 1 & 0 & 12 \\
\hline 2012 & 605 & 3 & 1 & 0 & 4 \\
\hline 2013 & 537 & 1 & 0 & 1 & 2 \\
\hline 2014 & 725 & 4 & 0 & 0 & 4 \\
\hline 2015 & 703 & 7 & 1 & 0 & 8 \\
\hline 2016 & 826 & 4 & 1 & 0 & 5 \\
\hline 2017 & 1048 & 10 & 3 & 0 & 13 \\
\hline TOTAL & 7821 & 67 & 12 & 4 & 83 \\
\hline
\end{tabular}

ADAS has identified 67 doping positive cases in 29 sports disciplines, while 12 doping positive cases have been identified by international sports federations (an internationally accepted abbreviation for IF). In addition, four other violations of anti-doping rules were identified. Analysing sports disciplines, most of the doping-positive cases in the period from 2006 to 2017 were in bodybuilding, followed by American football, wrestling, boxing and handball (Table 2). 
Table 2. Number of violations of anti-doping rules by sports

\begin{tabular}{|c|c|c|c|c|c|c|c|c|c|c|c|c|c|}
\hline Sports & ঠి & હे & 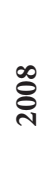 & ஓे & 융 & $\overline{\mathrm{D}}$ & $\stackrel{\sim}{\stackrel{\sim}{*}}$ & $\stackrel{n}{\stackrel{\sim}{\sim}}$ & $\underset{\text { d }}{\mathbb{D}}$ & $\frac{10}{8}$ & $\stackrel{0}{\stackrel{7}{\sim}}$ & $\widehat{ }$ & $\begin{array}{c}\text { Total number } \\
\text { of violations } \\
\text { by a } \\
\text { sports } \\
\text { branch }\end{array}$ \\
\hline Body building & & & & 1 & 5 & & 1 & & & & 1 & 3 & 11 \\
\hline American football & & & & & & 1 & 1 & & & 1 & 2 & 2 & 7 \\
\hline Wrestling & & & 4 & & 2 & & & & & 1 & & & 7 \\
\hline Boxing & & & & & 4 & 1 & 1 & & & & 1 & & 7 \\
\hline Handball & & & & & 3 & 1 & & & 1 & & & & 5 \\
\hline Basketball & & & & & 1 & 2 & & & & 1 & & & 4 \\
\hline Athletics & & & 1 & & 2 & & & & 1 & 1 & & & 5 \\
\hline Judo & & & & 1 & & 1 & & & & & & 2 & 4 \\
\hline Weight lifting & & & 1 & & & 1 & 1 & & & & & & 3 \\
\hline Cycling & & & 1 & & & 2 & & & & & & & 3 \\
\hline Volleyball & & & & & & & & & & 1 & & 1 & 2 \\
\hline Kayak / canoe & & & & 1 & & & & & & & & & 1 \\
\hline Tennis & & & & & 1 & & & 1 & & & & & 2 \\
\hline Football & & & & & 1 & & & & & & 1 & & 2 \\
\hline Rugby 13 & & & & & 2 & & & & & & & 1 & 3 \\
\hline Kickboxing & & & & & & 1 & & & 1 & & & & 2 \\
\hline Ice Hockey & & & & & & 1 & & & & & & 1 & 2 \\
\hline Water polo & & & & & & & & & & 1 & & 1 & 2 \\
\hline Bob & 1 & & & & & & & & & & & & 1 \\
\hline Karate & & & 1 & & & & & & & & & & 1 \\
\hline Rowing & & & 1 & & & & & & & & & & 1 \\
\hline Shooting & & & & 1 & & & & & & & & & 1 \\
\hline FEI / Jockey & & & & & & 1 & & & & & & & 1 \\
\hline Taekwondo & & & & & & & & 1 & & & & 1 & 2 \\
\hline Rafting & & & & & & & & & & 1 & & & 1 \\
\hline Kyokushinkai & & & & & & & & & & 1 & & & 1 \\
\hline Motor sport & & & & & & & & & & 1 & & & 1 \\
\hline Sambo & & & & & & & & & & & & 1 & 1 \\
\hline $\begin{array}{c}\text { Total of violations } \\
\text { in the sport of } \\
\text { Serbia }\end{array}$ & 1 & $\mathbf{0}$ & 9 & 4 & 21 & 12 & 4 & 2 & 3 & 9 & 5 & 13 & 83 \\
\hline
\end{tabular}


In the next step of the analysis of doping violations of Serbian athletes, 92 different prohibited substances were identified, predominantly from groups: anabolic agents, stimulants, diuretics, cannabinoids, beta-blockers and beta- 2 agonists (Table 3 ).

Table 3. The presence of forbidden substances in doping positive athletes

\begin{tabular}{ccc}
\hline Groups of forbidden substances & Number of violations & $\begin{array}{c}\text { Participation of the Prohibited } \\
\text { Substance in } \\
\text { Anti-doping violation (\%) }\end{array}$ \\
\hline Anabolic agents & 30 & 33 \\
Stimulants & 20 & 22 \\
Cannabinoids & 18 & 19 \\
Diuretics and masking agents & 18 & 19 \\
Hormones and metabolic modulators & 4 & 4 \\
Beta 2 agonists & 1 & 1 \\
Beta blockers & 1 & 1 \\
\hline
\end{tabular}

The Anti-Doping Agency of the Republic of Serbia has been trying to implement animal doping controls from the beginning. It succeeded in doing so, and as of 2008, it has been doing it continuously, with a vari- able number of detected doping violations in horses. What is worrying is the analysis of doping animals and positive findings, that it is always above the world average (Table 4).

Table 4. Number of doping controls on horses by years and the number of anti-doping rule violations $\left({ }^{*} 37\right.$ positive horses and 2 other violations of anti-doping rules - denial of control)

\begin{tabular}{|c|c|c|c|c|c|c|c|c|c|c|c|}
\hline Year & 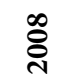 & ठ্ণি & 웅 & $\overline{\check{\lambda}}$ & ָั่ & $\stackrel{m}{\stackrel{n}{*}}$ & $\stackrel{4}{\Delta}$ & 水 & $\stackrel{\circ}{\stackrel{2}{2}}$ & 气ิ & ฮี \\
\hline $\begin{array}{l}\text { Number of tested } \\
\text { horses }\end{array}$ & 49 & 27 & 60 & 68 & 35 & 36 & 56 & 58 & 60 & 60 & 509 \\
\hline $\begin{array}{l}\text { Number of violations } \\
\text { found in horses* }\end{array}$ & 5 & 2 & 4 & 6 & 1 & 4 & 6 & 3 & 6 & 2 & 39 \\
\hline $\begin{array}{l}\text { Percentage of } \\
\text { violations (\%) }\end{array}$ & 10.2 & 7.40 & 6.67 & 8.82 & 2.85 & 11.11 & 10.71 & 5.17 & 10 & 3.33 & 7.66 \\
\hline
\end{tabular}

\section{Doping control outside the competition, national registered test group and exemption for therapeutic use}

In the next step of its development, ADAS has realized educational, research, and organizational activities within its "clean and sport zero tolerance for doping" mission. Accordingly, the National Registered
Testing Group (RTG) is formed in Serbia, enabling the fight against doping outside of the competition. The first registered test group was formed in 2007 and 2008 and has counted about 600 athletes. Since 2009, the number of athletes has been reduced to below 200 of the 18 sporting branches, while in 2017 there were only 78 athletes. The dynamics of the number of athletes in RTG is the result of WADA recommendations, but the outcome of ADAS's long-term effort on the organizational and ethical integration of the Serbian sports system. 
Table 5. Frequency of unavailability for non-contest testing, as well as number of notifications due to missed testing and failure to complete location forms

\begin{tabular}{cccc}
\hline Year & $\begin{array}{c}\text { Number of } \\
\text { RTG members }\end{array}$ & Number of missed test notifications & $\begin{array}{c}\text { Number of notifications } \\
\text { for failure to complete } \\
\text { Location Forms }\end{array}$ \\
\hline 2007 & 280 & 0 & 0 \\
2008 & 320 & 0 & 0 \\
2009 & 167 & 0 & 47 \\
2010 & 114 & 7 & 35 \\
2011 & 96 & 10 & 11 \\
2012 & 126 & 7 & 31 \\
2013 & 103 & 4 & 10 \\
2014 & 119 & 3 & 17 \\
2015 & 113 & 5 & 2 \\
2016 & 70 & 9 & 10 \\
2017 & 78 & 19 & 1 \\
\hline
\end{tabular}

Persistence on realization of organizational and ethical integration of the Serbian sports and society system towards zero doping tolerance, professional competence of members as well as the leadership role of ADAS in promoting human and sport oriented towards the athlete and his needs has resulted in the following results, about facts which should be observed in the function of the new sports-medical paradigm of Serbia's sport. First of all, sports branches of im-

Table 6. Sports branches and number of athletes in RTG

\begin{tabular}{lc}
\hline Sports branch & $\begin{array}{c}\text { Average number of athletes } \\
\text { in RTG } \\
(\mathbf{2 0 0 7 - 2 0 1 7 )}\end{array}$ \\
\hline Athletics & 21 \\
Rowing & 11 \\
Kayak & 10 \\
Swimming & 9 \\
Cycling & 9 \\
Wrestling & 9 \\
Weight lifting & 9 \\
Tennis & 8 \\
Karate & 6 \\
Kickboxing & 6 \\
Taekwondo & 6 \\
\hline
\end{tabular}

portance for RTGs have been determined, followed by their differentiation according to the number of members (athletics, rowing, kayaking and swimming are presented with the largest number of members in RTG). The incidence of injuries and chronic diseases among the members of the group was determined (most injuries and chronic diseases are registered within sports with the highest number of members in RTG). (Table 6)

\begin{tabular}{lc}
\hline Sports branch & $\begin{array}{c}\text { Average number of athletes } \\
\text { in RTG } \\
(\mathbf{2 0 0 7 - 2 0 1 7 )}\end{array}$ \\
\hline Judo & 5 \\
Paralympic sports & 4 \\
Biathlon & 3 \\
Bodybuilding & 3 \\
Boxing & 3 \\
Triathlon & 2 \\
Handball & 2 \\
Shooting & 2 \\
Rugby 13 & 1 \\
basketball & 1 \\
Fencing & 1 \\
\hline
\end{tabular}


Athletes with chronic illness and injuries who use a drug with the presence of a substance from the List of Prohibited Doping Substances pass through the Therapeutic Use Exemption Protocol (TUE). This protocol has been implemented in ADAS since 2007. Since then, by the end of 2017, 226 TUE protocols have been approved. The number of applications varies year by year, but what follows is qualitative improvement of relations within different professions in the Serbian sports system. Thus, the awareness of sports workers, trainers, administrative staff, and especially team doctors and athletes about this problem develops through continuous education conducted by ADAS, it can be said, at a weekly level. (Table 7, Figure 1). It is important to emphasize that ADAS aims to bring this process closer, easier and to direct it to the fast healing of athletes.

Table 7. The aetiology of the medical condition for which TUE is required (2007-2018)

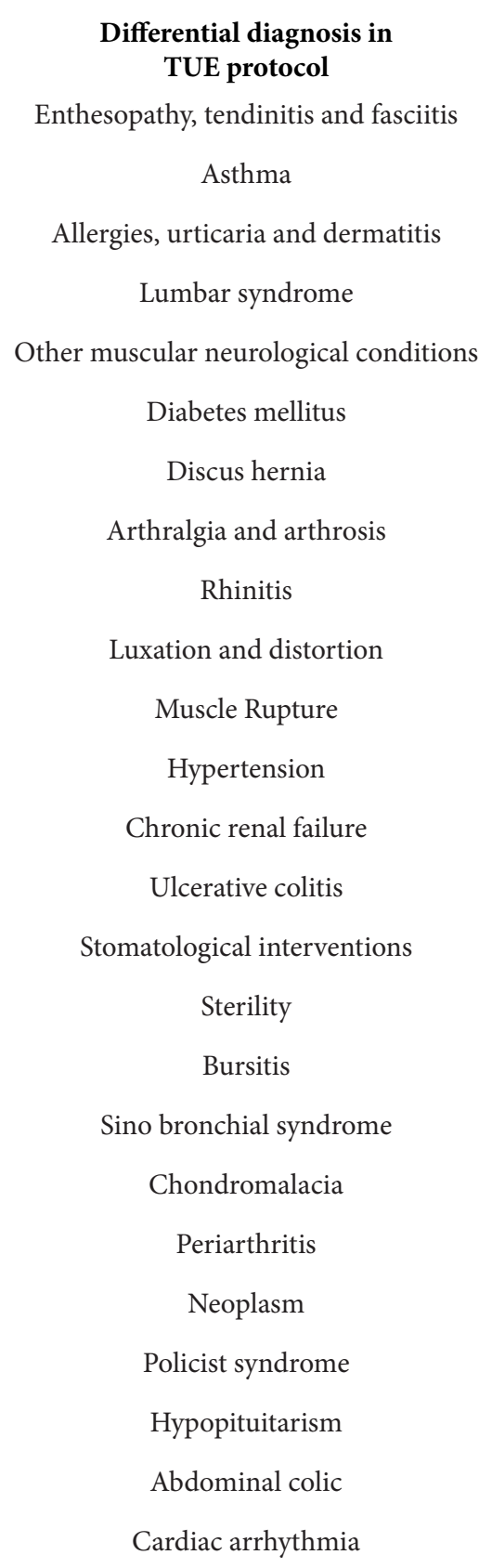

\begin{tabular}{|c|c|}
\hline $\begin{array}{l}\text { Number of } \\
\text { athletes }\end{array}$ & $\begin{array}{c}\text { participatior } \\
(\%)\end{array}$ \\
\hline 36 & 15.93 \\
\hline 30 & 13.27 \\
\hline 27 & 12.12 \\
\hline 24 & 10.44 \\
\hline 22 & 9.56 \\
\hline 14 & 6.11 \\
\hline 12 & 5.13 \\
\hline 9 & 3.81 \\
\hline 8 & 3.72 \\
\hline 8 & 3.36 \\
\hline 6 & 2.83 \\
\hline 5 & 2.30 \\
\hline 4 & 1.95 \\
\hline 3 & 1.42 \\
\hline 3 & 1.42 \\
\hline 3 & 1.42 \\
\hline 2 & 0.97 \\
\hline 2 & 0.97 \\
\hline 1 & 0.44 \\
\hline 1 & 0.44 \\
\hline 1 & 0.44 \\
\hline 1 & 0.44 \\
\hline 1 & 0.44 \\
\hline 1 & 0.44 \\
\hline 1 & 0.44 \\
\hline
\end{tabular}




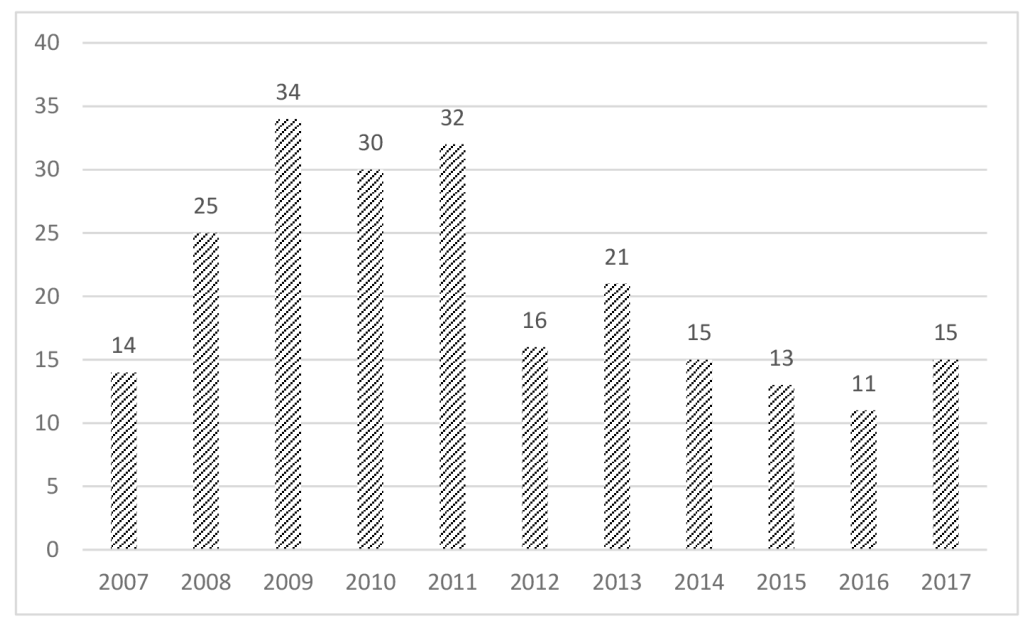

Picture 1. Number of TUE applications by year

The list of the most frequently used substances reported and approved for use through TUE protocols in more than $70 \%$ of cases were glucocorticosteroids (Table 8).

Table 8. Medications because of which TUE was requested (2007-2018)

\begin{tabular}{|c|c|c|}
\hline Substance & Number & $\begin{array}{c}\text { Participation } \\
\text { (\%) }\end{array}$ \\
\hline Betamethasone & 48 & 21.24 \\
\hline Methylprednisolone & 43 & 19.03 \\
\hline Dexamethasone & 39 & 17.26 \\
\hline Local corticosteroids & 30 & 13.19 \\
\hline Insulin & 16 & 7.08 \\
\hline Salbutamol & 15 & 6.55 \\
\hline Prednisolone & 7 & 3.10 \\
\hline Formoterol & 6 & 2.83 \\
\hline Phenoterol & 4 & 1.77 \\
\hline Spironolactone & 3 & 1.42 \\
\hline Bisoprolol & 3 & 1.33 \\
\hline Hydrocortisone & 2 & 0.97 \\
\hline $\begin{array}{l}\text { HMG - human menopausal } \\
\text { gonadotropin }\end{array}$ & 2 & 0.97 \\
\hline Furosemide & 1 & 0.44 \\
\hline Erythropoietin & 1 & 0.44 \\
\hline Propranolol & 1 & 0.44 \\
\hline DHEA and pregnanolone & 1 & 0.44 \\
\hline Growth hormone & 1 & 0.44 \\
\hline Infusion & 1 & 0.44 \\
\hline Ephedrine & 1 & 0.44 \\
\hline TOTAL & 226 & \\
\hline
\end{tabular}


The use of approved substances through the TUE protocol was equally systemic and local, while for the rest the inhalator was used.

Table 9. Application of substances for which TUE was approved

\begin{tabular}{c|c}
\hline Way of application & $\begin{array}{c}\text { participation } \\
(\mathbf{\%})\end{array}$ \\
\hline Systemic (intramuscular) & 39 \\
Local (most often intra-articular) & 39 \\
Inhalation & 22 \\
\hline
\end{tabular}

\section{INNOVATIVE SIDE OF ADAS}

With the aim of a comprehensive, timely, antidoping protection for the athlete's health, and, above all, optimal utilization of qualitative foreign supplements in the construction of sports results, since 2011, the institution of consulting and giving opin- ions on drugs and supplements has been introduced. In order to avoid misunderstandings, both at the level of the administrative and medical teams of NSF, that is, coaching and medical teams in the athlete's environment, all opinions on drugs and supplements are given in writing, and can be obtained after an electronic inquiry.

Table 10. Opinions on drugs (260) issued at the athletes' requests according to different groups of medications in the period $(2011-2017$.)

\begin{tabular}{l|c}
\hline Group of medications & Participation (\%) \\
\hline Antibacterials for systemic use & 10.14 \\
Nasal preparations & 8.70 \\
Anti-inflammatory and ant rheumatic products & 7.25 \\
Analgesics & 6.52 \\
Antihistamines for systemic use & 5.07 \\
Drugs that affect the renin-angiotensin system & 4.35 \\
Drugs used in obstructive pulmonary disease & 4.35 \\
Full hormones and genital system modulators & 4.35 \\
Drugs for acidity disorders & 3.62 \\
Antibiotics and chemotherapeutics for dermatological use & 2.90 \\
Psychoanaleptics & 2.90 \\
Psycholeptics & 2.90 \\
Diuretics & 2.17 \\
Corticosteroids, dermatological preparations & 2.17 \\
\hline
\end{tabular}




\begin{tabular}{|c|c|}
\hline Group of medications & Participation (\%) \\
\hline Drug-acting drugs & 2.17 \\
\hline Medicines for functional gastrointestinal disorders & 2.17 \\
\hline Muscle relaxants (myorelaxants) & 2.17 \\
\hline Vasoprotectives & 2.17 \\
\hline Antianemics & 1.45 \\
\hline Antiepileptics & 1.45 \\
\hline Antimycotic for dermatological use & 1.45 \\
\hline Beta blockers of adrenergic receptors & 1.45 \\
\hline Corticosteroids for systemic use & 1.45 \\
\hline Drugs used in diabetes (antidiabetics) & 1.45 \\
\hline Ear medications (otologists) & 1.45 \\
\hline Local products for muscle and joint pain & 1.45 \\
\hline Thyroid Gland Therapy & 1.45 \\
\hline Vitamins & 1.45 \\
\hline Anesthetics & 0.72 \\
\hline Antithrombotic agents (anticoagulants) & 0.72 \\
\hline Antiviral drugs for systemic use & 0.72 \\
\hline Herbal preparations for the respiratory system & 0.72 \\
\hline Gynecological anti-infective and antiseptics & 0.72 \\
\hline Laxatives & 0.72 \\
\hline Drugs against cough and colds & 0.72 \\
\hline Other gynecological drugs & 0.72 \\
\hline Other drugs that affect the nervous system & 0.72 \\
\hline Serum lipid lowering agents (hypolipemics) & 0.72 \\
\hline $\begin{array}{l}\text { Anti-inflammatory agents, including antihistamines, } \\
\text { anesthetics, and the like. }\end{array}$ & 0.72 \\
\hline Therapy of heart disease & 0.72 \\
\hline Urological drugs & 0.72 \\
\hline
\end{tabular}


Table 11. Opinions on supplements (380) were issued at the request of athletes according to different groups of supplements (2011 - 2017)

\begin{tabular}{|c|c|}
\hline Type of supplements & Participation (\%) \\
\hline Fat Burner & 9.47 \\
\hline Whey protein & 8.95 \\
\hline NO reactor & 8.68 \\
\hline Multicomponent preparations & 6.58 \\
\hline Creatine & 6.05 \\
\hline Tribulus & 5.79 \\
\hline Herbal preparations & 4.74 \\
\hline Amino acids - complex & 4.21 \\
\hline Increase energy carbohydrates & 3.95 \\
\hline Weight gain - genders & 3.95 \\
\hline Amino acids - glutamine & 3.68 \\
\hline Antioxidants & 3.68 \\
\hline Preparations for the protection of the joints & 3.68 \\
\hline Multivitamins and multi-minerals & 3.16 \\
\hline Amino acids - BCAA & 2.89 \\
\hline Increased energy - caffeine & 2.63 \\
\hline Increase in testosterone and growth hormone & 2.37 \\
\hline Sports drink & 2.11 \\
\hline Amino acid - beta alanine & 1.84 \\
\hline Carnitine & 1.32 \\
\hline Magnesium & 1.32 \\
\hline Amino acid - arginine & 1.05 \\
\hline Zinc & 1.05 \\
\hline Melatonin & 1.05 \\
\hline Preparations with guarana & 1.05 \\
\hline Omega fatty acids & 0.79 \\
\hline Prohibited substances - hormones and stimulants & 0.79 \\
\hline vitamin C & 0.53 \\
\hline An enzyme complex & 0.53 \\
\hline Selenium & 0.53 \\
\hline Replacement for meal & 0.53 \\
\hline Collagen & 0.26 \\
\hline Protein chocolate & 0.26 \\
\hline Multi-minerals & 0.26 \\
\hline Multivitamins & 0.26 \\
\hline
\end{tabular}




\section{ADAS STAFF IN THE FIGHT FOR NATIONAL AND INTERNATIONAL SPORT}

Today, the Anti-Doping Agency of Serbia has 71 doping controllers, among which there is one Doping Delegate to the LEN (European Swimming Federation), one Doping Delegate to the EA (European Athletic Federation), one Anti-Doping Panel in the World Wrestling Federation (UWW), four licensed doping UEFA controllers, two UIAA licensed doping controllers, and two "supervising" doctors of FIBA (International Basketball Federation). Dr Nenad Dikić, PhD, is the Vice President of the Medical Council of FIBA Europe, and the President of the TUE Commission of the International Federation of Water Skiing. Dr Marija Anđelković is the president of the Anti-Doping Commission of the World Hiking Federation. The experience gained internationally influenced the quality of work in the country. Doping controllers of ADAS conducted training and doping control at the Paralympic Games in Athens (2004), the Winter Olympic Games in Vancouver (2010), the Olympic and Paralympic Games in London (2012), the First Olympic Games of Europe in Baku (2015), the Olympic and Paralympic Games in Rio (2016), Paralympic Games in Pyongyang (2018).

The number and variation of doping control that ADAS has performed over the last 5 years is due to. "Intelligent testing", which according to the technical document for specific testing in sport (TDSAA) requires the exact number of growth hormone tests and erythropoietin, the introduction of a biological passport and blood testing, which is one of the conditions for proclaiming an anti-doping organization competent. All of this demanded a redistribution of funds intended for laboratory analysis and, consequently, a smaller number of basic analyses of urine.

Today, in addition to standard urine analysis, special analyses of erythropoietin and release of the growth hormone factor, as well as the analysis of blood due to the biological passport and the growth hormone analysis, are carried out. Although no injuries of anti-doping rules have been recorded in Serbia, the total number of injuries of the anti-doping rule is not only related to urine, but also to interference with doping control, avoidance of doping control, possession of doping agents and doping of drugs to athletes (Table 1). These controls were conducted in all sports that were recognized in the sports system of Serbia, so that in 29 sports (Table 2) there were registered doping positive athletes who consumed 92 different substances (Table 3). Curiosity is the opinion of most sports experts, who claimed during the establishment of ADAS that the Agency does not need us because there is no doping in Serbia. It turned out that our athletes behave in an identical way as their colleagues from the world, even the five most commonly used substances are completely identical to those used by "foreign" athletes. A similar opinion existed among experts on horse racing. However, for the first year it has been shown that the number of doping positive horses is significantly higher and varies from 3 to 10 times more than in the world (Table 4).

The Anti-Doping Agency of Serbia is one of the first agencies in the region that started using the $\mathrm{AD}$ AMS database for athletes, with the aim of implementing all obligations towards WADA and optimizing control processes. Filling out and submitting the site templates was initially at the level of mail posting and personal filling in to ADAS, to develop until today's electronic use of the ADAMS database. In the registered test group, top athletes, national and international athletes, and doping positive athletes were always in place to meet all the criteria of the World Anti-Doping Agency. Each member of the test group is timely notified of non-fulfilment of obligations regarding availability for testing ("reminders" if the form is not delivered within the set deadline for each quarter). Three violations in any combination for 12 months can lead to suspension of participation in sports for two years. The violations of anti-doping rules related to location patterns decreased over the years exclusively thanks to the constant education ADAS conducted and never reached the number of 3 offenses in 12 months, and therefore Serbian athletes were never punished for failing to fulfil obligations in RTG (Table 6).

Approval of the exemption for therapeutic use was carried out by the TUE Committee at the level of Serbia. All requests were approved according to a procedure that often involved the search for additional documentation in order to verify the diagnosis and necessity of therapy (Table 7). The number of TUE varied from year to year, and all TUE applications submitted by ADAS on behalf of athletes of Serbia to international federations were accepted, as they respected the adopted procedures. Confidence in ADAS activities is a sign of high operationalization 
of procedures and standards of quality in professional contacts with IF (Picture 1).

Prohibited substances requiring a 70\% TUE protocol were glucocorticosteroids, although their therapeutic effect was in doubt in many situations. Chronic diseases are not well known to athletes, so education remains the only way for athletes to understand which drugs can lead to positive results on doping control (Table 8).

Another basic activity related to ADAS is education. ADAS holds regular annual seminars in the field of combating doping in sports and doping animals. On average, it organizes an educational session per week. In the course of 2015 and 2016, the Congress on the prevention of doping in sport was organized. The Anti-Doping Agency of the Republic of Serbia can boast a unique approach to athletes in terms of education, and this can be said in accordance with all international standards. Serbian athletes who are also scholars of the Ministry of Youth and Sports (on average about 350) are obliged to sign a scholarship agreement, to attend two lectures in the field of antidoping during the year. In the past 6 years, ADAS, in addition to doping topics, also educated athletes in sports medicine, nutrition and supplements, and in accordance with their interest. Regular educational activity follows the publication of books and publications. Some of the ADAS editions are the book " 100 questions about doping” by Dr Nenad Dikić, PhD., a bilingual book "The Other Side of the Medal" by author Marija Midžović, in which sports and culture experts are familiar with the phenomenon of doping, as well as participation in the editions of the Association for Sports Medicine of Serbia "White Book - Team Doctor" and "Practical Sports Nutrition".

\section{CLEAN SPORT, HEALTHY GROWING AND FIGHT AGAINST DOPING AND ADDICTIONS}

As an equally important approach to the promotion of the clean-sport campaign, ADAS's vision for Serbia is in the place where children and young people grow up healthy (physiological, psychological, emotional, social, environmental...). The pilot project on peer education in the fight against doping started at the beginning of 2016 under the auspices of the
Anti-Doping Agency of the Republic of Serbia. The initiator of the project was Dr Snežana Rajačić from the Medical School "Nadežda Petrović" in Zemun, where on several occasions voluntary study of doping was studied through the topic of elective lectures. For the first time in our country, the idea was born to launch peer education, where high school students would conduct education about the harmfulness of doping among their peers. Dr Marija Anđelkovic gave lectures and taught them to become young educators. Nine students, who showed a high level of interest, became the first young educators on the harmfulness of doping, and managed to educate about 7000 students of primary and secondary schools in Belgrade and Serbia in a year. This activity and the success that was achieved did not remain unnoticed, it was awarded by the Ministry of Youth and Sports and it was continued in 2017 as a project of the National Youth Strategy "The Young Rule" in cooperation with the Adventure Association. Nine students who trained thousands of students in the pilot project became instructors who created a network of young educators in Belgrade (7 educators), Nis (17), Novi Sad (28) and Kragujevac (7). Newly-educated young educators are students of medical schools, active athletes and students of other professions and schools. In total, since the beginning of this project (2016), in the past two years about 10,000 students attended a lecture on the fight against doping.

\section{NATIONAL PROJECTS OF ADAS - ANTIDOPING AGENCY OF THE $21^{\text {ST }}$ CENTURY}

Since 2011, the Anti-Doping Agency of Serbia has launched a project related to the previous "doping free" verification of the production series of individual supplements. The tested batches are marked with a label stating that this preparation is "doping free" to anabolic and steroidal administration. This practically means that ADAS has started to check the contents of the preparation before they are released for sale. By analysing in the accredited laboratory of the World Anti-Doping Agency, a whole series of the given supplement is verified whether it contains steroids and / or stimulants as a doping substance. Doping pure supplements are labelled "doping free". Each reference number on the stamp corresponds to the verified serial number of the supplements. The Athlete on the ADAS website can check the correctness of series on the doping. 
Additionally, ADAS has developed two services through which, in a direct way, it advises athletes in the area of medication, sports nutrition and supplements. It can be said that these services are a real curiosity on a global scale. Namely, by giving opinions on supplements and drugs taken by athletes, ADAS took over part of the responsibility for the composition that is written on the box of preparations. In the period from 2011 to 2017, 640 products were analysed, of which 260 medications and 380 supplements. The complexity of the problem certainly requires a deeper pharmacological analysis, but only a random view of Tables 8, 9 and 10, on groups of drugs and supplements used by athletes in Serbia, points to the need for a more thorough understanding of medicines and supplements that can bring an athlete into a serious health problem, doping rules and why personal caution is needed. The complete logistics provided by ADAS provided to athletes is not just a service, but above all an authentic type of cooperation in the fight against doping in sport.

For the full realization of the ADAS mission, cooperation with the state authorities in charge of controlling the distribution of doping funds is of great importance. There is also a legal basis for this, which is the Law on the Prevention of Doping in Sports. This law has prescribed a strict penal policy for offenders. In the past period, ADAS has already established cooperation with the Ministry of Interior, SBPOK, courts, prosecutors' offices and the Customs Administration, in the form of held working meetings and education, expertise and expert testimony in concrete cases. Only the decisive suppression of the distribution of doping funds, for which there is a clear legal basis, can lead to a real reduction in their use, not only in top-level but also in recreational sports, where this danger is greater, given that recreational sports are not covered by doping controls. In that sense, it would be of great importance to realize the already existing idea of forming an anti-doping department within SBPOK.

International confirmation of quality and standards in the work and operation of ADAS is also cooperation with international organizations. Thus, the cooperation takes place with the World Anti-Doping Agency on the project "Doctors and Doping in Sport: Experiences of the 8 Balkan Countries". The World Basketball Federation is working on four international projects. In cooperation with UNESCO, antidoping education projects are being implemented. Cooperation with international sports federations is equally important. ADAS cooperates with more than ten IFs, Council of Europe, Sport Chord, as well as with other well-known anti-doping organizations worldwide. The confirmation of the good work of ADAS in the field of anti-doping is the fact that the former Minister of Youth and Sports in the Government of the Republic of Serbia (2007-2012), Snežana Samardžić Marković, was a member of the Founder Committee of the World Anti-Doping Agency from 2009 to 2012, and now she is one of the four directors of the Council of Europe, among other things, responsible for preventing doping in sport. 


\section{ADAS SCIENTIFIC PRODUCTION - THE OUTCOME OF THE DECADE OF FIGHT AGAINST DOPING AND PROTECTION OF ATHLETES' HEALTH}

1. Kostic-Vucicevic M., Michalickova D., Dikic N., Stojmenovic T., Andjelkovic M., Nikolic I., Vukasinovic-Vesic M., Malic T. (2017). Food elimination based on immunoglobulin G antibodies improves gastrointestinal discomfort symptoms and sport performance in professional athletes. MED SPORT, 70, 480-94.

2. Curcic Dj., Stojmenovic T., Djukic-Dejanovic S., Dikic N., Vesic-Vukasinovic M. Radivojevic N., Andjelkovic M., Borovcanin M., Djokic G. (2017). Positive Impact of Prescribed Physical Activity on Symptoms of Schizophrenia: Randomized Clinical Trial. PSYCHIATRIA DANUBINA, 29 (4), 459-465.

3. Stankovic I., Michalickova D., Minic R., Kotur-Stevuljevic J., Miljkovic M., Kostic-Vucicevic M., Dikic N., Andjelkovic M., Baralic I., Ivanovic N., Djordjevic B. (2017). Changes in Parameters of Immunological and Oxidative Status in Elite Athletes During Winter (Meeting Abstract). MEDICINE AND SCIENCE IN SPORTS AND EXERCISE, 49 (5), Suppl. 1, 457-457.

4. Stajic A., Andjelkovic M., Dikic N., Rasic J., Vukasinovic-Vesic M., Ivanovic D., Jancic-Stojanovic B. (2017). Determination of higenamine in dietary supplements by UHPLC/MS/MS method. JOURNAL OF PHARMACEUTICAL AND BIOMEDICAL ANALYSIS, 146, 48-52.

5. Ujka K., Bruno R.M., Bastiani L., Bernardi E., Sdringola P., Dikic N., Basyal B., Bhandari S. S., Basnyat B., Cogo A., Pratali L. (2017). Relationship Between Occupational Physical Activity and Subclinical Vascular Damage in Moderate-Altitude Dwellers. HIGH ALTITUDE MEDICINE \& BIOLOGY, 18 (3), 249-257.

6. Andjelkovic M., Bjornsson E., De Bono V., Dikic N., Devue K., Ferlin D., Hanzevacki M., Jonsdottir F., Shakaryan M., Walser Sabine. (2017). The development and appraisal of a tool designed to find patients harmed by falsely labelled, falsified (counterfeit) medicines. BMC HEALTH SERVICES RESEARCH, 17, 419.

7. Banovic M., Nedeljkovic I., Stepanovic J., Giga V., Nedeljkovic M., Petrovic M., Dikic N., Beleslin B. (2017). The value of combined cardiopulmonary end stress-echocardiography testing in discovering latent hfpef in patients with hypertension and normal LV systolic and diastolic function at rest (Meeting Abstract). EUROPEAN JOURNAL OF HEART FAILURE, 19, Suppl. 1, 324-324.

8. Michalickova D., Kostic-Vucicevic M., Vukasinovic-Vesic M., Stojmenovic T., Dikic N., Andjelkovic M., Djordjevic B., Tanaskovic B., Minic R. (2017). L. helveticus Lafti ${ }^{\circledast} 10$ supplementation modulates mucosal and humoral immunity in elite athletes: a randomized double - blinded placebo - controlled trial. Journal of strength and conditioning research / National Strength \& Conditioning Association, 31 (1), 62-70.

1. Dikić, N. Jakovljević (2016). Sportska medicina. [Sports Medicine. In Serbian]. Kragujevac: Fakultet medicinskih nauka.

2. Nedeljkovic, I. P., Banovic, M.D., Stepanovic, J. M., Giga, V. L., Djordjevic - Dikic, A., Trifunovic, D. D., Nedeljkovic, M. A., Petrovic, M. Z., Dobric, M., Dikic, N., Zlatar, M., \& Beleslin, B. D. (2016) The combined exercise stress echocardiography and cardiopulmonary exercise test for identification of masked heart failure with preserved ejection fraction in patients with hypertension. EUROPEAN JOURNAL OF PREVENTIVE CARDIOLOGY. 23(1), 71-77.

3. Michalickova D., Minic R., Dikic N., Andjelkovic M., Kostic-Vucicevic M., Stojmenovic T., Nikolic I., Djordjevic B. (2016). Lactobacillus helveticus Lafti ${ }^{\circledast}$ L10 supplementation reduces respiratory infection duration in a cohort of elite athletes: a randomized double - blind placebo - controlled trial. Appl Physiol Nutr Metab., 41(7):782-9.

4. Marinkovic D., Minic R., Dikic N., Andjelkovic M., Vukasinovic-Vesic M., Kostic-Vucicevic M., Stojmenovic T., Nikolic I., Djordjevic B. (2016). The Effect of Lactobacillus Helveticus L10 Supplementation on Respiratory Infections and Mucosal Immunity in Elite Athletes (Meeting Abstract). JOURNAL OF CLINICAL GASTROENTEROLOGY, 50, Suppl. 2, S227-S228. 
5. Ujka K., Bruno R.M., Cogo A., Bastiani L., Marinoni A., Bernardi E., Sdringola P., Dikic N., Basyal 2016 B., Bhandari S.S., Basnyat B., Bonasoni P., Pratali L. (2016). Black carbon chronic exposure is associated with subclinical cardiovascular damage in Nepalese individuals (Meeting Abstract). EUROPEAN HEART JOURNAL, 37, Suppl. 1, str. 551-551.

1. Vukasinovic-Vesic M., Andjelkovic M., Stojmenovic T., Dikic N., Kostic M., Curcic Dj. (2015). Sweat rate and fluid intake in young elite basketball players on the FIBA Europe U20 Championship. VOJNOSANITETSKI PREGLED, 72 (12), 1063-1068.

2. Andjelkovic M., Baralic I., Djordjevic B., Kotur-Stevuljevic J., Radivojevic N., Dikic N., RadojevicSkodric S., Stojkovic M. (2015). Hematological and Biochemical Parameters in Elite Soccer Players During a Competitive Half Season. JOURNAL OF MEDICAL BIOCHEMISTRY, 34 (4), 460-466.

3. Baralic, I. R., Andjelkovic, M., Djordjevic, B. I., Dikic, N., Radivojevic, N. J., Suzin-Zivkovic, V., Radojevic-Skodric, S. M., Pejic, S. A. (2015). Effect of Astaxanthin Supplementation on Salivary IgA, Oxidative Stress, and Inflammation in Young Soccer Players. EVIDENCE-BASED COMPLEMENTARY AND ALTERNATIVE MEDICINE, 2015, 783761.

4. Vukasinovic-Vesic, M., Andjelkovic, M., Stojmenovic, T., Dikic, N., Kostic, M., Curcic, Dj. (2015). Sweat rate and fluid intake in young elite basketball players on the FIBA Europe U20 Championship, VOJNOSANITETSKI PREGLED, 72 (12), 1063-1068.

5. Andjelkovic, M., Baralic, I. R., Djordjevic, B. I., Kotur - Stevuljevic, J. M., Radivojevic, N. J., Dikic, N., Radojevic-Skodric, S. M., Stojkovic, M. V. (2015). Hematological and Biochemical Parameters in Elite Soccer Players During a Competitive Half Season. JOURNAL OF MEDICAL BIOCHEMISTRY. 34 (4), 460-466.

1. Dikić, N. \& Nedeljković, I. (2014). Stres test. [Stress test. In Serbian]. Beograd: Udruženje za sportsku kardiologiju Srbije.

2. Anđelković, M. \& Dikić, N. (2014). Metabolički fitnes [Metabolic Fitness. In Serbian]. Beograd: Udruženje za medicinu sporta Srbije.

3. Klisuras, V (2014). Sportska fizilogija. [Sports physiology]. N. Dikić (ed) Beograd: Udruženje za medicinu sporta Srbije.

4. Dikić, N. (2014). Zdravo srce za sve. [A healthy heart for all. In Serbian] Beograd: Udruženje za medicinu sporta Srbije.

5. Bruno R.M., Ujka K., Cogo A., Bernardi E., Dikic N., Sdringola P., Bashyal B., Bhandari S.S., Basnyat B., Pratali L. Relationship between habitual physical activity and arterial stiffness in Himalayan highaltitude dwellers (Meeting Abstract). EUROPEAN HEART JOURNAL, (2014), 35, 732-732.

1. Dikic N., McNamee M., Guenter H., Samardzic-Markovic S.,Vajgic B. (2013). Sports physicians, ethics and antidoping governance: between assistance and negligence. BRITISH JOURNAL OF SPORTS MEDICINE, 47 (11), 701-704.

2. Baralic I, Djordjevic B, Dikic N, Kotur-Stevuljevic J, Spasic S, Jelic-Ivanovic Z, Radivojevic N, Andjelkovic M, Pejic S. (2013). Effect of astaxanthin supplementation on paraoxonase 1 activities and oxidative stress status in young soccer players. Phytother Res., 27(10), 1536-42.

3. Andjelkovic M., Dikic N., Vukasinovic-Vesic M., Mikovic N., Baralic I., Antic T. (2013).

4. Lifestyle Interventions in Obesity Treatment (Meeting Abstract). ANNALS OF NUTRITION AND METABOLISM, 63, Suppl. 1, 1370-1370.

5. Baralic I., Djordjevic B., Andjelkovic M., Dikic N., Kotur-Stevuljevic J., Dimitrijevic Lj., Antic T., Vukasinovic-Vesic M., Radojevic-Skodric S. (2013). Effects of Astaxanthin Supplementation on Dna Stability and Paraoxonase 1 Activity in Young Soccer Players (Meeting Abstract). ANNALS OF NUTRITION AND METABOLISM, 63, Suppl. 1, 772-772.

6. Djordjevic B., Baralic I., Andjelkovic M., Dikic N., Antic T., Vukasinovic-Vesic M., Blazencic-Mladenovic V., Popovic M., Radojevic-Skodric S., Dietary Intakes and Eating Habits of Elite Athletes in Serbia: Are They Follow the Current Sports Nutrition Standards? (Meeting Abstract). ANNALS OF NUTRITION AND METABOLISM, 63, Suppl. 1, 771-772. 


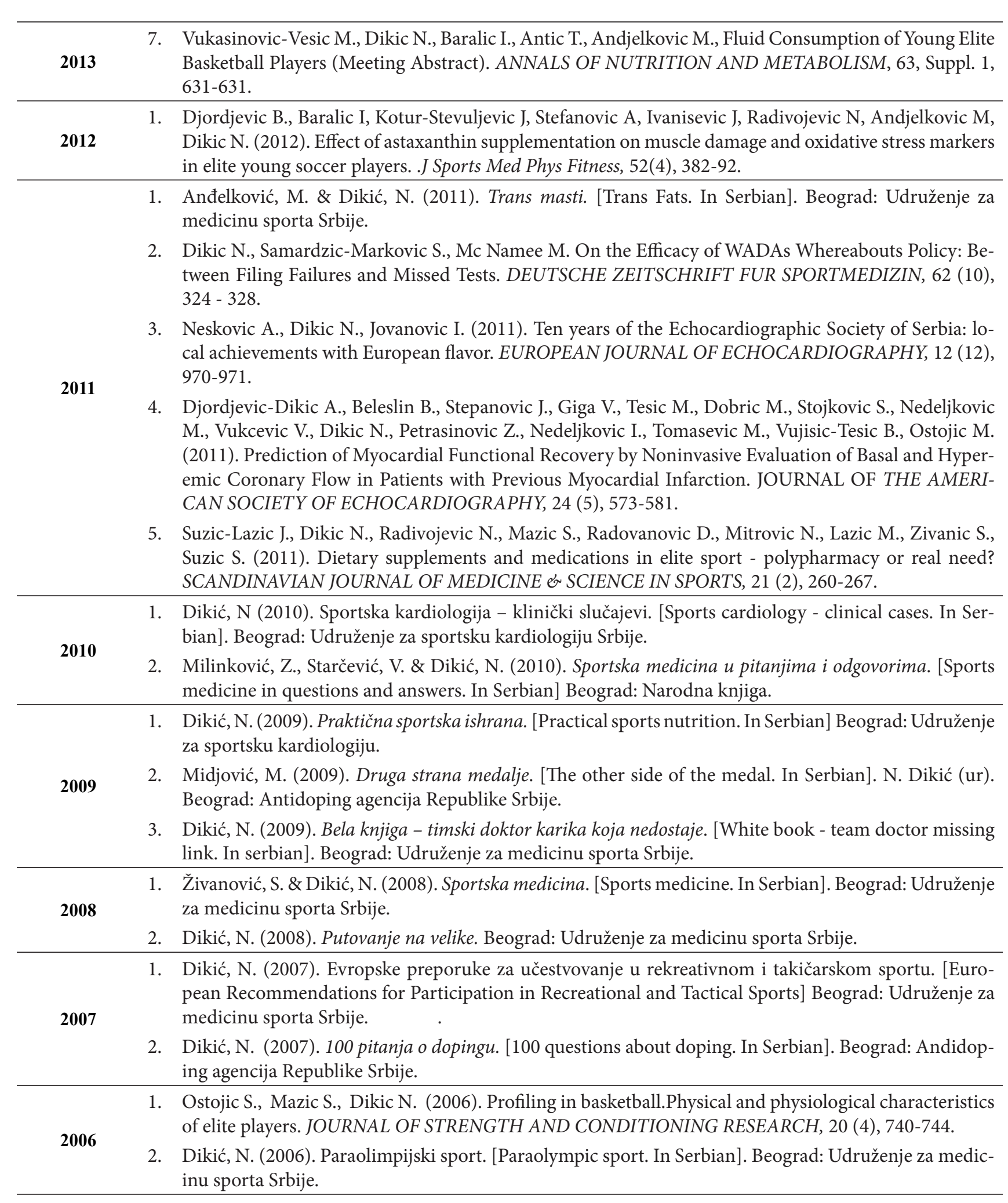




\section{CONCLUSION}

In just over a decade, the Anti-Doping Agency of the Republic of Serbia has grown into one of the most representative institutions of sports and society in Serbia. With knowledge and work, ADAS has become not only a partner of sports organizations in the country, but also a large number of organizations in the world. By its professionalism and impartial and responsible interpretation of the World Anti-Doping Code, in quality and in accordance with the norms, ADAS has coordinated work with the latest amendments to international regulations and has become one of the best Agencies in the region. Nevertheless, despite clear international recognition, for ADAS the most important is confidence it has gained in athletes in the fight for fair and clean sport.

\section{Acknowledgments}

I thank first of all my first associates: Dr Milica Vukašinovic Vesić, who continued everything I started as ADAS Director, Dr Marija Anđelković, who with her incredible energy and knowledge covered all the areas of anti-doping, Bojan Vajagić, without whom ADAS would have no integrity, Borislav Jakovljević and Mirko Stefanović, who care that ADAS will be a financially impeccable institution and finally Milos Cvjetičanin, who showed that the place of the system administrator is something that every modern institution should have. I thank Dr Nenad Đurđević, $\mathrm{PhD}$, on the successfully written Law on the Prevention of Doping in Sports, as well as all members of the Board of Directors, the Anti-Doping Committee and the TUE Committee. I also thank all doping controllers who have not only passed through ADAS, but have already incorporated a part of themselves in the past decade. I equally thank Dr Natalija Milčić Matić and her team who used to undergo doping control of horses at times and under adverse conditions and did a lot for animal welfare. Our research and writing would not be possible without the support of prof. Dr Vladimir Jakovljević, prof. Dr Brižita Đorđević and Dr Slobodan Živanić, PhD. Finally, we thank everyone who supported us during the past decade, including prof. Dr Branislav Jevtić, who not only understood us, but also significantly influenced the problem of supplementation in sports. 


\title{
АНТИДОПИНГ АГЕНЦИЈА - ЗНАЊЕ, КАДРОВИ, ИНОВАЦИЈЕ У БОРБИ ЗА ЧИСТ НАЦИОНАЛНИ СПОРТ
}

\author{
Ненад Дикић \\ Факултет за физичку културу и менаџмент у спорту, Универзитет Сингидунум, Београд, Србија, \\ Антидопинг агенција Републике Србије
}

\begin{abstract}
Сажетак
Антидопинг агенција Републике Србије (АДАС) је основана Законом о спречавању допинга у спорту 2005. године, а са радом је почела 1. јануара 2006. године. Суштина борбе против допинга у Србији је везана са усвајањем Закона о спречавању допинга у спорту 2005. и 2014. године. Тренутно, АДАС има 71 допинг контролора, укључујући ту и 8 контролора за животиње. Допинг контролори АДАС-а су обучени за контроле на домаћим, али и великим међународним такмичењима. Од оснивања па до данас, урађена је 7821 допинг контрола, откривено 67 допинг позитивних случајева у 29 спортова у земљи, док је 12 допинг позитивних случаја откривено од стране интернационалних федерација. Осим тога, забележене су 4 друге повреде антидопинг правила. Од оснивања па до краја 2017. године, одобрено је 226 ТУЕ, али је још важније да се свест спортских радника, нарочито тимских лекара, постепено развијала кроз едукацију коју АДАС спроводи у просеку једном недељно. Антидопинг агенција Републике Србије је само током једне деценије израсла у једну од најпоштованијих установа у спорту, која је знањем и радом постала не само партнер спортским организацијама у земљи, него и великом броју организација у свету.
\end{abstract}

Кључне речи: АНТИДОПИНГ / НАЦИОНАЛНА АГЕНЦИЈА / ИНОВАЦИЈЕ / СРБИЈА

\section{УВОД}

Антидопинг агенција Републике Србије (АДАС) је основана Законом о спречавању допинга у спорту који је 2005. године усвојен у Парламенту Републике Србије. Са радом је почела 1. јануара 2006. године и тако, у новим законским и организационим условима, наставила са борбом против допинга у спорту коју је у периоду од 2003 - 2005. године водило Удружење за медицину спорта Србије. Од самог оснивања АДАС је планирала своје активности у три правца, са циљем реализације мисије и својих програмских активности, а то су: спровођење допинг контроле, едукација и истраживање.

Борба против допинга у Србији је деценијски проблем и изазов којиусвојунајинтензивнијуфазу улази усвајањем Закона о спречавању допинга у спорту (2005. и 2014. године). Упориште напорима система спорта и друштва Србије, у борби против допинга у спорту, налази се у међународним стручним и политичким конвенцијама које су потврђене одлукама Парламента Републике Србија и законски обликоване кроз закон о потврђивању међународне конвенције против допинга у спорту 2009. године и законе о спорту из 2011. и 2016. године. Усвајањем конвенције и доношењем закона, Република Србија је исказала вредносну оријентацију према проблемима и изазовима савременог спорта. Тиме је испунила своје међународне обавезе у области борбе против допинга у спорту и сврстала се у ред држава које су формално-правно прихватиле Светски антидопинг кодекс чиме је појединцима и тимовима из Србије омогућено да учествују на свим међународним такмичењима, односно да се националне спортске федерације кандидују и буду биране за организацију истих. АДАС је, према изјави Светске антидопинг агенције, у потпуности ускладила свој рад са последњим изменама Светског антидопинг кодекса, које су на снази од 1. јануара 2015. 
Дикић Н., Антидопинг агенција - знање, кадрови, иновације..., ФИЗИЧКА КУЛТУРА 2019; 73 (1): $72-88$

Поред испуњавања закључака међународних спортских, здравствених, хуманитарних и политичких организација, АДАС карактерише континуиран, интензиван рад на изградњи организационих, технолошких али и иновационих искорака које данас испуњава под руководством директора и управног одбора од 15 чланова, уз рад антидопинг одбора од 9 чланова, ТУЕ одбора од 3 члана, одбора за допинг контролу са 71 допинг контролором, укључујући и 8 контролора за животиње. Квалитет и висок стандард у реализације мисије АДАС-а је верификованим и уговорима са међународним федерацијама за кошарку (ФИБАЕвропа) и планинарство (УИАА), као и многим другим интернационалним федерацијама. Од оснивања АДАС је радио допинг контроле на преко 100 међународних такмичења, укључујући ту и контроле на највећим мултиспортским такмичењима којима је била домаћин Србија, а то су Европски олимпијски фестивал младих (ЕЈОФ - 2007) и Универзијада (2009).

Сходно наведеном, проблем овог рада се односи на антидопинг политику која се спроводи у Републици Србији, односно месту и улози националне антидопинг агенције у формирању и раду оваквог националног тела, усвајању кодекса и законске регулативе, борбе за смањење промета забрањених супстанци на територији Србије, рад на оспособљавању и усавршавању допинг контролора, образовни програми са спортистима, тренерима, спортским организацијама али и грађанима, изрицање санкција и праћење њихове реализације, сарадња са спортским организацијама свих нивоа, сарадња с акредитованим антидопинг лабораторијама... Метод примењен у сачињавању овог рада се може дефинисати као методолошки комплексан јер се до дедукције о проблему стиже кроз методе неексперименталног посматрања, рефлексије и анализе случаја.

\section{АНТИДОПИНГ АГЕНЦИЈА СРБИЈЕ - ДЕКАДА ИЗАЗОВА И РАЗВОЈА}

\section{Период развоја кроз утврђивање антидопинг прекршаја.}

Антидопинг агенција Србије је у претходних 12 година имала значајан напредак у броју урађених допинг контрола. Од оснивања па до данас, урађено је 7821 допинг контрола на домаћим и иностраним такмичењима, почевши са 2006. годином када је урађена 31 допинг контрола па до 2017. која је завршена са 1048 урађених допинг контрола (Табела 1).

Табела 1 Број допинг контрола по годинама, број допинг позитивних случајева АДАС и ИФ и друге повреде антидопинг правила

\begin{tabular}{|c|c|c|c|c|c|}
\hline Године & $\begin{array}{l}\text { Укупан број тестираних } \\
\text { спортиста по годинама }\end{array}$ & $\begin{array}{c}\text { Број допинг } \\
\text { позитивних } \\
\text { спортиста АДАС }\end{array}$ & $\begin{array}{c}\text { Број допинг } \\
\text { позитивних } \\
\text { спортиста ИФ }\end{array}$ & $\begin{array}{c}\text { Друге повреде } \\
\text { антидопинг правила }\end{array}$ & $\begin{array}{l}\text { Укупно прекршаја } \\
\text { антидопинг правила }\end{array}$ \\
\hline 2006 & 31 & 1 & 0 & 0 & 1 \\
\hline 2007 & 347 & 0 & 0 & 0 & 0 \\
\hline 2008 & 494 & 7 & 1 & 1 & 9 \\
\hline 2009 & 767 & 2 & 1 & 1 & 4 \\
\hline 2010 & 717 & 17 & 3 & 1 & 21 \\
\hline 2011 & 1021 & 11 & 1 & 0 & 12 \\
\hline 2012 & 605 & 3 & 1 & 0 & 4 \\
\hline 2013 & 537 & 1 & 0 & 1 & 2 \\
\hline 2014 & 725 & 4 & 0 & 0 & 4 \\
\hline 2015 & 703 & 7 & 1 & 0 & 8 \\
\hline 2016 & 826 & 4 & 1 & 0 & 5 \\
\hline 2017 & 1048 & 10 & 3 & 0 & 13 \\
\hline УкУПно & 7821 & 67 & 12 & 4 & 83 \\
\hline
\end{tabular}


АДАС је утврдила 67 допинг позитивних случајева у 29 спортских дисциплина, док je 12 допинг позитивних случаја утврђено од стране међународних спортских федерација (међународно прихваћена скраћеница на енгл. ИФ). Осим тога, утврђене су и четири друге повреде антидопинг правила. Анализирајући по спортским гранама, највећи број допинг позитивних случајева у периоду од 2006. до 2017. био у бодибилдингу, а одмах затим следе амерички фудбал, рвање, бокс и рукомет (Табела 2).

Табела 2 Број повреда антидопинг правила по спортовима

\begin{tabular}{|c|c|c|c|c|c|c|c|c|c|c|c|c|c|}
\hline Спортови & 2006 & 2007 & 2008 & 2009 & 2010 & 2011 & 2012 & 2013 & 2014 & 2015 & 2016 & 2017 & $\begin{array}{c}\text { Укупно } \\
\text { прекршаја по } \\
\text { спортској грани }\end{array}$ \\
\hline Бодибилдинг & & & & 1 & 5 & & 1 & & & & 1 & 3 & 11 \\
\hline Амерички фудбал & & & & & & 1 & 1 & & & 1 & 2 & 2 & 7 \\
\hline Рвање & & & 4 & & 2 & & & & & 1 & & & 7 \\
\hline Бокс & & & & & 4 & 1 & 1 & & & & 1 & & 7 \\
\hline Рукомет & & & & & 3 & 1 & & & 1 & & & & 5 \\
\hline Кошарка & & & & & 1 & 2 & & & & 1 & & & 4 \\
\hline Атлетика & & & 1 & & 2 & & & & 1 & 1 & & & 5 \\
\hline Џудо & & & & 1 & & 1 & & & & & & 2 & 4 \\
\hline Дизање тегова & & & 1 & & & 1 & 1 & & & & & & 3 \\
\hline Бициклизам & & & 1 & & & 2 & & & & & & & 3 \\
\hline Одбојка & & & & & & & & & & 1 & & 1 & 2 \\
\hline Кајак/кану & & & & 1 & & & & & & & & & 1 \\
\hline Тенис & & & & & 1 & & & 1 & & & & & 2 \\
\hline Фудбал & & & & & 1 & & & & & & 1 & & 2 \\
\hline Рагби 13 & & & & & 2 & & & & & & & 1 & 3 \\
\hline Кик бокс & & & & & & 1 & & & 1 & & & & 2 \\
\hline Хокеј на леду & & & & & & 1 & & & & & & 1 & 2 \\
\hline Ватерполо & & & & & & & & & & 1 & & 1 & 2 \\
\hline Боб & 1 & & & & & & & & & & & & 1 \\
\hline Карате & & & 1 & & & & & & & & & & 1 \\
\hline Веслање & & & 1 & & & & & & & & & & 1 \\
\hline Стрељаштво & & & & 1 & & & & & & & & & 1 \\
\hline ФЕИ/џокеј & & & & & & 1 & & & & & & & 1 \\
\hline Теквондо & & & & & & & & 1 & & & & 1 & 2 \\
\hline Рафтинг & & & & & & & & & & 1 & & & 1 \\
\hline Кјокушинкаи & & & & & & & & & & 1 & & & 1 \\
\hline Мото спорт & & & & & & & & & & 1 & & & 1 \\
\hline Самбо & & & & & & & & & & & & 1 & 1 \\
\hline $\begin{array}{c}\text { Укупно прекршаја } \\
\text { у спорту Србије }\end{array}$ & 1 & 0 & 9 & 4 & 21 & 12 & 4 & 2 & 3 & 9 & 5 & 13 & 83 \\
\hline
\end{tabular}

У следећем кораку анализе допинг прекршаја спортиста Србије утврђено је коришћење 92 различите забрањене супстанце, доминантно из група: анаболичких агенаса, стимуланса, диуретика, канабиноида, бета блокатора и бета2-агонисти (Табела 3). 
Дикић Н., Антидопинг агенција - знање, кадрови, иновације..., ФИЗИЧКА КУЛТУРА 2019; 73 (1): $72-88$

Табела 3 Заступљеност забрањених супстанци код допинг позитивних спортиста

\begin{tabular}{lcc}
\hline Групе забрањених супстанци & Број прекршаја & $\begin{array}{c}\text { Учешће забрањене супстанце } \\
\text { у антидопинг прекршају (\%) }\end{array}$ \\
\hline Анаболички агенси & 30 & 33 \\
Стимуланси & 20 & 22 \\
Канабиноиди & 18 & 19 \\
$\begin{array}{l}\text { Диуретици и маскирајући } \\
\text { агенси }\end{array}$ & 18 & 4 \\
$\begin{array}{l}\text { Хормони и метаболички } \\
\text { модулатори }\end{array}$ & 4 & 1 \\
Бета 2 агонисти & 1 & 1 \\
Бета блокатори & 1 & 4 \\
\hline
\end{tabular}

Антидопинг агенција Републике Србије се од почетка трудила да спроведе допинг контролу животиња. У томе је и успела, тако да то од 2008. године чини у континуитету, са променљивим бројем утврђених допинг прекршаја коња. Оно што је забрињавајући податак анализе допинга животиња и утврђених позитивних налаза, да је он увек изнад светског просека (Табела 4 ).

Табела 4 Број допинг контрола на коњима по годинама и број повреда антидопинг правила ( 37 позитивних коња и 2 друге повреде антидопинг правила - одбијање контроле)

\begin{tabular}{lccccccccccc}
\hline Година & $\mathbf{2 0 0 8}$ & $\mathbf{2 0 0 9}$ & $\mathbf{2 0 1 0}$ & $\mathbf{2 0 1 1}$ & $\mathbf{2 0 1 2}$ & $\mathbf{2 0 1 3}$ & $\mathbf{2 0 1 4}$ & $\mathbf{2 0 1 5}$ & $\mathbf{2 0 1 6}$ & $\mathbf{2 0 1 7}$ & Укупно \\
\hline $\begin{array}{l}\text { Број тестираних } \\
\text { коња }\end{array}$ & 49 & 27 & 60 & 68 & 35 & 36 & 56 & 58 & 60 & 60 & 509 \\
$\begin{array}{l}\text { Број прекршаја } \\
\text { утвђених код } \\
\text { коња }\end{array}$ & 5 & 2 & 4 & 6 & 1 & 4 & 6 & 3 & 6 & 2 & 39 \\
\hline $\begin{array}{l}\text { Проценат } \\
\text { прекршаја (\%) }\end{array}$ & $\mathbf{1 0 , 2}$ & $\mathbf{7 , 4 0}$ & $\mathbf{6 , 6 7}$ & $\mathbf{8 , 8 2}$ & $\mathbf{2 , 8 5}$ & $\mathbf{1 1 , 1 1}$ & $\mathbf{1 0 , 7 1}$ & $\mathbf{5 , 1 7}$ & $\mathbf{1 0}$ & $\mathbf{3 , 3 3}$ & $\mathbf{7 , 6 6}$ \\
\hline
\end{tabular}

\section{Контрола на допинг изван \\ такмичења, национална \\ регистрована тест група и изузеће \\ ради терапијске употребе}

У следећем коракусвог развоја АДАС реализује образовне, истраживачке, организационе активности унутар своје мисије „чистог и спорта нулте толеранције на допинг“. Сходно томе у Србији се формира Национална регистрована тест група (РТГ) чиме је омогућено спровођење борбе против допинга изван такмичења. Прва регистрована тест група је формирана током 2007. и 2008. године и је бројала око 600 спортиста. Од 2009. године број спортиста је сведен на испод 200 из 18 спортских грана, да би је у 2017. години чинило само 78 спортиста. Динамика броја спортиста у РTГ је резултат препорука WADA-e, али је исход вишегодишњег напора АДАС-а на организационој и етичкој интеграцији система спорта Србије. 
Дикић Н., Антидопинг агенција - знање, кадрови, иновације..., ФИЗИЧКА КУЛТУРА 2019; 73 (1): $72-88$

Табела 5 Учесталост недоступности за тестирање изван такмичења, као и број опомена због пропуштеног тестирања и непопуњавања образаца о локацији

\begin{tabular}{cccc}
\hline Година & Број чланова РТГ & $\begin{array}{c}\text { Број опомена због пропуштеног } \\
\text { теста }\end{array}$ & $\begin{array}{c}\text { Број опомена због непопуњавања } \\
\text { образаца о локацији }\end{array}$ \\
\hline 2007 & 280 & 0 & 0 \\
2008 & 320 & 0 & 0 \\
2009 & 167 & 0 & 47 \\
2010 & 114 & 7 & 35 \\
2011 & 96 & 10 & 31 \\
2012 & 126 & 7 & 11 \\
2013 & 103 & 4 & 17 \\
2014 & 119 & 3 & 2 \\
2015 & 113 & 5 & 10 \\
\hline
\end{tabular}

Истрајавање на реализацији организационе и етичке интеграције система спорта и друштва Србије према нултој толеранцији на допинг, професионална компетентност чланова као и лидерска функција АДАС-а у промовисању хуманог и спорта оријентисаног према спортисти и његовим потребама, донела је следеће резултате о којима говоре чињенице које треба посматрати у функцији нове спортско-медицинске парадигме спорта Србије. Пре свега, утврђене су спортске гране од значаја за РТГ, следила је њихова диференцијација према броју чланова (атлетика, веслање, кајак и пливање су представљени са највећим бројем чланова у РТГ). Утврђена је учесталост повређивања и хроничних обољења код чланова групе (највећи број повреда и хроничних обољења је регистрован унутар спортова са највећим бројем чланова у РТГ). (Табела 6)
Табела 6 Спортске гране и број спортиста у РТГ

\begin{tabular}{|c|c|}
\hline Спортска грана & $\begin{array}{c}\text { Просечан број спортиста у РТГ } \\
(2007-2017)\end{array}$ \\
\hline Атлетика & 21 \\
\hline Веслање & 11 \\
\hline Кајак & 10 \\
\hline Пливање & 9 \\
\hline Бициклизам & 9 \\
\hline Рвање & 9 \\
\hline Дизање тегова & 9 \\
\hline Тенис & 8 \\
\hline Карате & 6 \\
\hline Кик бокс & 6 \\
\hline Теквондо & 6 \\
\hline Џудо & 5 \\
\hline Параолимпијски спортови & 4 \\
\hline Биатлон & 3 \\
\hline Бодибилдинг & 3 \\
\hline Бокс & 3 \\
\hline Триатлон & 2 \\
\hline Рукомет & 2 \\
\hline Стрељаштво & 2 \\
\hline Рагби 13 & 1 \\
\hline Кошарка & 1 \\
\hline Мачевање & 1 \\
\hline
\end{tabular}


Спортисти са хроничним обољењима и повредама који користе лек са присуством неке од супстанци са Листе забрањених допинг супстанци пролазе кроз протокол Изузеће ради терапеутске употребе (енгл. TUE). Овај протокол се у АДАС-у спроводи од 2007. године. Од тада па до краја 2017. године одобрено је 226 TUE протокола. Број пријава варира из године у годину, али оно што прати овај простор је квалитативно унапређење односа унутар различитих професија у систему спорта Србије. Тако се свест спортских радника, тренера, административног особља, а нарочито тимских лекара и спортиста о овом проблему развија кроз континуирану едукацију коју спроводи АДАС, може се рећи на недељном нивоу. (Табела 7, Слика 1). Важно је нагласити да АДАС тежи да овај процес приближи, олакша и усмери ка брзом оздрављењу спортиста.

Табела 7 Етиологија здравственог стања због којих је захтеван TUE (2007-2018)

\begin{tabular}{|c|c|c|}
\hline $\begin{array}{c}\text { Диференција дијагноза у } \\
\text { TUE протоколу }\end{array}$ & $\begin{array}{c}\text { Број } \\
\text { спортиста }\end{array}$ & $\begin{array}{c}\text { Заступљеност } \\
\text { (\%) }\end{array}$ \\
\hline Ентезитис, тендинитис и фасцитис & 36 & 15,93 \\
\hline Астма & 30 & 13,27 \\
\hline Алергије, уртикарија и дерматитис & 27 & 12,12 \\
\hline Лумбални синдром & 24 & 10,44 \\
\hline Остала мишићно неуролошка стања & 22 & 9,56 \\
\hline Дијабетес мелитус & 14 & 6,11 \\
\hline Дискус хернија & 12 & 5,13 \\
\hline Артралгија и артрозе & 9 & 3,81 \\
\hline Ринитис & 8 & 3,72 \\
\hline Луксација и дисторзија & 8 & 3,36 \\
\hline Руптуре мишића & 6 & 2,83 \\
\hline Хипертензија & 5 & 2,30 \\
\hline Хронична бубрежна инсуфицијенција & 4 & 1,95 \\
\hline Улцерозни колитис & 3 & 1,42 \\
\hline Стоматаолошке интервенције & 3 & 1,42 \\
\hline Стерилитет & 3 & 1,42 \\
\hline Бурзитис & 2 & 0,97 \\
\hline Синобронхијални синдром & 2 & 0,97 \\
\hline Хондромалација & 1 & 0,44 \\
\hline Периартритис & 1 & 0,44 \\
\hline Неоплазма & 1 & 0,44 \\
\hline Полицистични синдром & 1 & 0,44 \\
\hline Хипопитуитаризам & 1 & 0,44 \\
\hline Абдоминалне колике & 1 & 0,44 \\
\hline Срчана аритмија & 1 & 0,44 \\
\hline
\end{tabular}




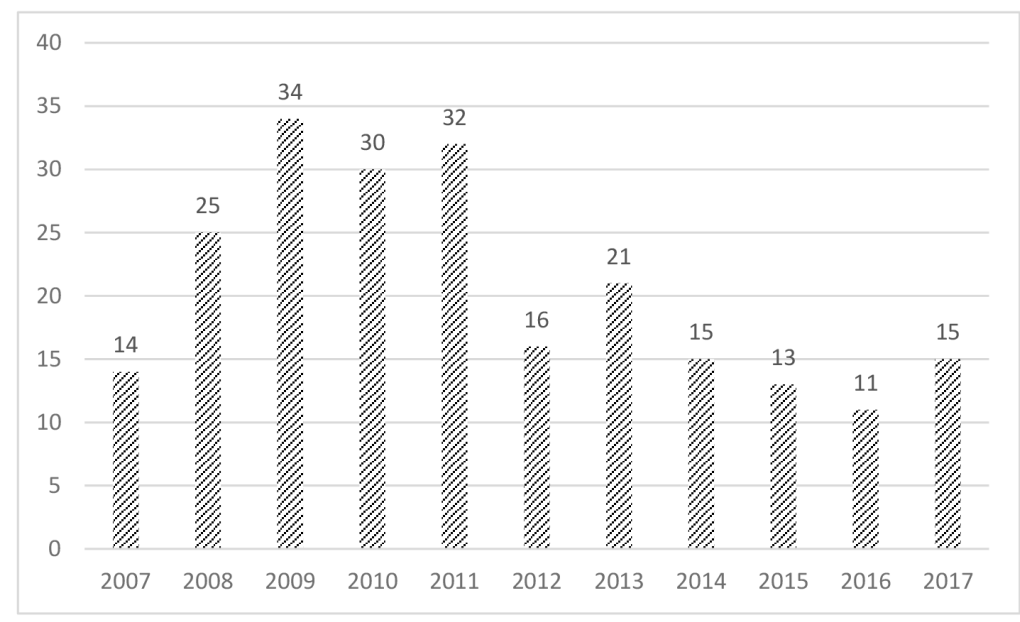

Слика 1 Број TUE пријава по годинама

Листа најчешће коришћених супстанци које су пријављене и одобрене за коришћење кроз TUE протоколе, у више од 70\% случајева, су били глукокортикостероиди (Табела 8 ).

Табела 8. Лекови због којих је захтеван ТУЕ (2007-2018)

\begin{tabular}{|c|c|c|}
\hline Супстанца & Број & Заступљеност (\%) \\
\hline Бетаметазон & 48 & 21,24 \\
\hline Метилпреднизолон & 43 & 19,03 \\
\hline Дексаметазон & 39 & 17,26 \\
\hline Локални кортикостероиди & 30 & 13,19 \\
\hline Инсулин & 16 & 7,08 \\
\hline Салбутамол & 15 & 6,55 \\
\hline Преднизолон & 7 & 3,10 \\
\hline Формотерол & 6 & 2,83 \\
\hline Фенотерол & 4 & 1,77 \\
\hline Спиронолактон & 3 & 1,42 \\
\hline Бисопролол & 3 & 1,33 \\
\hline Хидрокортизон & 2 & 0,97 \\
\hline $\begin{array}{l}\text { ХМГ - хумани менопаузни } \\
\text { гонадотропин }\end{array}$ & 2 & 0,97 \\
\hline Фуросемид & 1 & 0,44 \\
\hline Еритропоетин & 1 & 0,44 \\
\hline Пропранолол & 1 & 0,44 \\
\hline ДХЕА и прегнанолон & 1 & 0,44 \\
\hline Хормон раста & 1 & 0,44 \\
\hline Инфузија & 1 & 0,44 \\
\hline Ефедрин & 1 & 0,44 \\
\hline УКУПно & 226 & \\
\hline
\end{tabular}


Дикић Н., Антидопинг агенција - знање, кадрови, иновације..., ФИЗИЧКА КУЛТУРА 2019; 73 (1): $72-88$

Примена одобрених супстанци кроз TUE док је остатак био инхалаторно. протокол је био подједнако системски и локално,

Табела 9 Начин примене супстанци за које је одобрен TUE

\begin{tabular}{cc}
\hline Начин примене & $\begin{array}{c}\text { Заступљеност } \\
(\%)\end{array}$ \\
\hline Системски (интрамускуларно) & 39 \\
Локално (најчешће интраартикуларно) & 39 \\
Инхалаторно & 22 \\
\hline
\end{tabular}

\section{ИНОВАТИВНА СТРАНА АДАС-а}

Са циљем целовите, правовремене, по здравље спортисте, антидопинг заштите и, надасве, оптималне искоришћености квалитативне стране суплемената у изградњи спортског резултата, од 2011. године је уведена институција саветовања и давања мишљења о лековима и суплементима. Да би се избегли неспоразуми, како на нивоу административних и медицинских тимова НСФ, односно тренерских и медицинских тимова у окружењу спортисте, сва мишљења о лековима и суплементима су дата писано, а могу се добити након електронског упита.

Табела 10 Мишљења о лековима (260) издата на захтев спортиста према различитим групама лекова у периоду (2011 - 2017.)

\begin{tabular}{lc}
\hline Група лекова & $\begin{array}{c}\text { 3аступљеност } \\
\text { (\%) }\end{array}$ \\
\hline Антибактеријски лекови за системску примену & 10,14 \\
Назални препарати & 8,70 \\
Антиинфламаторни и антиреуматски производи & 7,25 \\
Аналгетици & 6,52 \\
Антихистаминици за системску примену & 5,07 \\
Лекови који делују на ренин-ангиотензин систем & 4,35 \\
Лекови који се примењују у опструктивној плућној & 4,35 \\
болести & 4,35 \\
Полни хормони и модулатори гениталног система & 3,62 \\
Лекови за поремећаје ацидитета & 2,90 \\
Антибиотици и хемиотерапеутици за дерматолошку & 2,90 \\
примену & 2,90 \\
Психоаналептици & 2,17 \\
Психолептици & 2,17 \\
Диуретици & 2,17 \\
Кортикостероиди, дерматолошки препарати & \\
Лекови који делују на око & \\
\hline
\end{tabular}


Дикић Н., Антидопинг агенција - знање, кадрови, иновације..., ФИЗИЧКА КУЛТУРА 2019; 73 (1): $72-88$

\begin{tabular}{|c|c|}
\hline Група лекова & $\begin{array}{c}\text { Заступљеност } \\
(\%)\end{array}$ \\
\hline $\begin{array}{l}\text { Лекови за функционалне гастроинтестиналне } \\
\text { поремећаје }\end{array}$ & 2,17 \\
\hline Мишићни релаксанси (миорелаксанси) & 2,17 \\
\hline Вазопротективи & 2,17 \\
\hline Антианемици & 1,45 \\
\hline Антиепилептици & 1,45 \\
\hline Антимикотици за дерматолошку примену & 1,45 \\
\hline Блокатори бета адренергичких рецептора & 1,45 \\
\hline Кортикостероиди за системску примену & 1,45 \\
\hline $\begin{array}{l}\text { Лекови који се употребљавају у дијабетесу } \\
\text { (антидијабетици) }\end{array}$ & 1,45 \\
\hline Лекови за ухо (отологици) & 1,45 \\
\hline Локални производи за болове у мишићима и зглобовима & 1,45 \\
\hline Терапија болести штитасте жлезде (тиреоидеје) & 1,45 \\
\hline Витамини & 1,45 \\
\hline Анестетици & 0,72 \\
\hline Антитромботичка средства (антикоагуланси) & 0,72 \\
\hline Антивирусни лекови за системску примену & 0,72 \\
\hline Биљни препарати за респираторни систем & 0,72 \\
\hline Гинеколошки антиинфективи и антисептици & 0,72 \\
\hline Лаксативи & 0,72 \\
\hline Лекови против кашља и прехладе & 0,72 \\
\hline Остали гинеколошки лекови & 0,72 \\
\hline Остали лекови који делују на нервни систем & 0,72 \\
\hline Средства која смањују липиде у серуму (хиполипемици) & 0,72 \\
\hline $\begin{array}{l}\text { Средства против свраба, укључујући антихистаминике, } \\
\text { анестетике и сл. }\end{array}$ & 0,72 \\
\hline Терапија болести срца & 0,72 \\
\hline Уролошки лекови & 0,72 \\
\hline
\end{tabular}


Дикић Н., Антидопинг агенција - знање, кадрови, иновације..., ФИЗИЧКА КУЛТУРА 2019; 73 (1): $72-88$

Табела 11 Мишљења о суплементима (380) издата на захтев спортиста према различитим групама суплемената $(2011$ - 2017)

\begin{tabular}{lc}
\hline Врста суплемента & 3аступљеност (\%) \\
\hline Сагоревач масти & 9,47 \\
Whеу протеин & 8,95 \\
NO реактор & 8,68 \\
Мултикомпонентни препарати & 6,58 \\
Креатин & 6,05 \\
Трибулус & 5,79 \\
Биљни препарати & 4,74 \\
Аминокиселине - комплекс & 4,21 \\
Повећање енергије угљени хидрати & 3,95 \\
Повећање телесне тежине - гејнери & 3,95 \\
Аминокиселине - глутамин & 3,68 \\
Антиоксиданси & 3,68 \\
Препарати за заштита зглобова & 3,68 \\
Мултивитамини и мултиминерали & 3,16 \\
Аминокиселине - БЦАА & 2,89 \\
Повећање енергије - кофеин & 2,63 \\
Повећање тестостерона и хормона раста & 2,37 \\
Спортско пиће & 0,26 \\
Аминокиселина - бета аланин & 0,26 \\
Карнитин & 0,26 \\
Магнезијум & 0,53 \\
Аминокиселина - аргинин & 1,84 \\
Цинк & 0,53 \\
Мелатонин & 0,53 \\
Препарати са гуараном & 1,32 \\
Омега масне киселине & 1,32 \\
Забрањене супстанце - хормони и стимуланси \\
Витамин Ц & 1,05 \\
Комплекс ензима & 1,05 \\
Селен & 05 \\
Замена за оброк & 05 \\
Протеинска чоколадица & 05 \\
Мултиминерали & 0,26 \\
\hline
\end{tabular}




\section{КАДРОВИ АДАС-а У БОРБИ ЗА ЧИСТ НАЦИОНАЛНИ И МЕБУНАРОДНИ СПОРТ}

Антидопинг агенција Србије данас има 71 допинг контролора, између осталих, има једног допинг делегата у ЛЕН (Европска пливачка федерација), једног допингделегатауЕА (Европска атлетска федерација), једног члана антидопинг панела у светској рвачкој федерацији (UWW), четири лиценцирана допинг контролора УЕФА (Унија европских фудбалских асоцијација), два лиценцирана допинг контролора УИАА (Светска пењачка и планинарска федерација), као и два „супервајзинг” доктора ФИБА (Интернационална кошаркашка федерација). Проф. др Ненад Дикић је потпредседник медицинског савета ФИБА Европе, и председник ТУЕ комисије Међународне федерације за скијање на води. Др Марија Анђелковић је председник антидопинг комисије Светске планинарске федерације. Искуство стечено на интернационалном плану је утицало на квалитет рада у земљи. Допинг контролори АДАС спроводили су едукацију и допинг контролу на Параолимпијским играма у Атини (2004), Зимским олимпијским играма у Ванкуверу (2010), Олимпијским и Параолимпијским играма у Лондону (2012), Првим олимпијским играма Европе у Бакуу (2015), Олимпијским и Параолимпијским играма у Рију (2016), Параолимпијским играма у Пјонг Чангу (2018).

Број и варирање допинг контрола које је АДАС обавила током последњих 5 година је настао услед. „интелигентног тестирања“, које према техничком документу за специфично тестирање у спорту (ТДСАА) захтева тачно одређен број тестова хормона раста и еритропроетина, увођење биолошког пасоша и тестирање крви, што представља један од услова за проглашење једне антидопинг организације компетентном. Све то је захтевало прерасподелу средстава намењених за лабораторијске анализе и самим тим мањи број основних анализа урина.

Данас поред стандардне анализе урина, спроводе се посебне анализе на еритропроетин и ослобађајући фактор хормона раста, као и анализа крви због биолошког пасоша, али и анализе хормона раста. Иако у Србији није забележена ни једна повреда антидопинг правила анализом крви, укупан број повреда антидопинг правила се не односи само на урин, већ и на ометање допинг контроле, избегавање допинг контроле, поседовање допинг средстава и давање допинг средства спортистима (Табела 1). Наведене контроле су спроведене у свим спортовима који су препознати у систему спорта Србије, да би у 29 спортова (Табела 2) забележени допинг позитивни спортисти који су конзумирали 92 различите супстанце (Табела 3). Куриозитет је мишљење већине спортских стручњака, који су тврдили приликом оснивања АДАС да нама Агенција не треба, јер у Србији нема допинга. Испоставило се да се наши спортисти понашају у свему идентично са својим колегама из света, чак су и пет најчешће коришћених супстанци потпуно идентичне оним који користе „страни“ спортисти. Слично мишљење је постојало и међу стручњацима на коњичким тркама. Међутим, већ прве године показало се да је број допинг позитивних коња знатно већи и да варира од 3 до 10 пута више него у свету (Табела 4).

Антидопинг агенција Србије је једна од првих агенција у региону која је започела коришћење АДАМС базе података за спортисте, а са циљем спровођења свих обавеза према WADA и оптимизације процеса контрола. Попуњавање и слање образаца о локацији је у почетку било на нивоу слања података поштом и личног попуњавања у АДАС-у, да би се развило до данашњег електронског коришћења АДАМС базе података. У регистрованој тест групи су се увек налазили врхунски спортисти, спортисти националног и међународног ранга, али и допинг позитивни спортисти, како би се испоштовали сви критеријуми Светске антидопинг агенције. Сваки члан тест групе се благовремено обавештава о неиспуњавању обавеза у погледу доступности за тестирање ("опомене" уколико образац није достављен у задатом року за сваки квартал). Три прекршаја у било којој комбинацији током 12 месеци могу да воде суспензији бављења спортом на две године. Број повреда антидопинг правила везан за обрасце о локацији се смањивао током година искључиво захваљујући константној едукацији коју је АДАС спроводио и никада није достигао број од 3 прекршаја у 12 месеци, па самим тим спортисти из Србије никада нису кажњени због неиспуњавања обавеза у РТГ (Табела 6). 
Дикић Н., Антидопинг агенција - знање, кадрови, иновације..., ФИЗИЧКА КУЛТУРА 2019; 73 (1): $72-88$

Одобрење изузећа ради терапијске употребе је на нивоу Србије спроводио ТУЕ Одбор. Сви захтевисубилиодобренипопроцедурикојајечесто подразумевала и тражење додатне документације ради верификовања дијагноза и неопходности терапије (Табела 7). Број ТУЕ је варирао из године у годину, а све ТУЕ пријаве које је АДАС у име спортиста Србије прослеђивала међународним федерацијама су биле прихваћене јер сеу њиховом доношењу поштују усвојене процедуре. Поверење према активностима АДАС-а је знак високе операционализације процедура и стандарда квалитета у професионалним контактима са ИФ (Слика 1).

Забрањене супстанце због којих се захтевало 70\% ТУЕпротокол субили глукокортикостероиди, иако се њихов терапијски ефекат у многим стањима доводио у питање. Хроничне болести су недовољно познате спортистима, тако да едукација остаје једини начин да спортисти разумеју који лекови могу довести до позитивног резултата на контроли на допинг (Табела 8).

Друга основна делатност везана за АДАС је едукација. АДАС одржава редовне годишње семинаре из области борбе против допинга у спорту и допинга животиња. У просеку реализује једну едукативну сесију недељно. Током 2015. и 2016. године организован је Конгрес о превенцији допинга у спорту. Антидопинг агенција Републике Србије може да се похвали јединственим приступом спортистима у погледу едукације и то може се рећи ради у складу са свим међународним стандардима. Спортисти Србије који су и стипендисти Министарства омладине и спорта (у просеку око 350) у обавези су према потписаном уговору о стипендирању, да слушају два предавања из области борбе против допинга током године. У протеклих 6 година АДАС је поред тема из области допинга вршио едукацију спортиста из спортске медицине, исхране и суплементације, а у складу са њиховим интересовањем. Редовну едукативну делатност прати издавање књига и публикација. Нека од издања АДАС су књига „100 питања о допингу“ проф. др Ненада Дикића, двојезична књига „Друга страна медаље“ ауторке Марије Миџовић, у којој познати из света спорта и културе говоре о феномену допинга, као и учествовање у издањима
Удружења за медицину спорта Србије „Бела књига - тимски лекар“ и „Практична спортска исхрана“.

\section{ЧИСТ СПОРТ, ЗДРАВО ОДРАСТАҢЕ И БОРБА ПРОТИВ ДОПИНГА И БОЛЕСТИ ЗАВИСНОСТИ}

Као подједнако важан приступ у афирмацији мисије борбе чистог спорта је и визија АДАС-а за Србију у којој деца и млади здраво одрастају (физиолошки, психички, емотивно, социјално, еколошки...). Пилот пројекат о вршњачкој едукацији у борби против допинга започет је почетком 2016. године под окриљем Антидопинг агенције Републике Србије. Иницијатор пројекта је била др Снежана Рајачић из Медицинске школе „Надежда Петровић” у Земуну где се у неколико наврата добровољно проучавала штетност допинга кроз тему изборних предавања. Тако се по први пут у нашој земљи родила идеја да се покрене вршњачка едукација, где средњошколци спроводе едукацију о штетности допинга међу својим вршњацима. Др Марија Анђелковић је са ученицима одржала предавања и обучила их да постану млади едукатори. Девет ученица, које су показале висок ниво интересовања, постале су први млади едукатори о штетности допинга и успеле су за годину дана да едукују око 7000 ученика основних и средњих школа Београда и Србије. Ова активност и успех који се изнедрио није остао непримећен, награђен је од стране Министарства омладине и спорта и настављен је у 2017. години као пројекат националне стратегије за младе „Млади су закон“у сарадњи са удружењем Авантура. Девет ученица које су оквиру пилот пројекта едуковале хиљаде ученика, постале су инструктори који су створили мрежу младих едукатора у Београду (7 едукатора), Нишу (17), Новом Саду (28) и Крагујевцу (7). Новоодабрани млади едукатори су ученици медицинских школа, активни спортисти и ученици других професија и школа. Укупно, од почетка овог пројекта (2016), за две године је око 10000 ученика одслушало предавање о борби против допинга. 


\section{НАЦИОНАЛНИ ПРОЈЕКТИ АДАС-а - АНТИДОПИНГ АГЕНЦИЈА 21. ВЕКА}

Антидопинг агенција Србије од 2011. године је отпочела пројекат везан за претходну „doping free“ верификацију произвођачке серије појединих суплемената. Проверене серије се обележавају налепницом на којој је написано да је тај препарат „doping free“ на анаболике и стероиде. То практично значи да је АДАС покренула проверу садржаја препарата пре њиховог пуштања у продају. Анализом у акредитованој лабораторији Светскеантидопинг агенције верификује се читава серија датог суплемента да ли садржи стероиде и-или стимулансе као допинг супстанце. Допинг чист суплемент се означава маркицом „doping free“. Сваки број референце на маркици одговара верификованом серијском броју суплемената. Спортиста на интернет презентацији АДАС-а може да провери исправност серије на допинг.

Поред тога АДАС је развила два сервиса путем којих, на директан начин, саветује спортисте у простору медикаментације, спортске исхране и суплементације. Може се рећи да су ови сервиси приличан куриозитет на светском нивоу. Наиме давањем мишљења о суплементима и лековима које узимају спортисти АДАС је преузео део одговорности за састав који је написан на кутији препарата. У периоду од 2011. до 2017. године анализирано је 640 препарата од тога 260 лекова и 380 суплемената. Комплексност проблема сигурно захтева дубљу фармаколошку анализу, али и само насумични поглед на табеле 8,9 и 10, на групе лекове и суплемента које користе спортисти Србије, указује на неопходност темељнијег разумевања лекова и суплемената који спортисту могу да уведу у озбиљан здравствени проблем, прекршај допинг правила и због чега је потребан лични опрез. Комплетна логистика од стране АДАС која је пружена спортистима није само сервис, већ и пре свега аутентичан вид сарадње у борби против допинга у спорту.
За пуну реализацији мисије АДАС је од изузетне важности сарадња и са државним органима који су задужени за сузбијање дистрибуције допинг средстава. За то постоји и законска основа, а то је Закон о спречавању допинга у спорту. Овај закон има прописану строгу казнену политику за прекршиоце. У протеклом периоду, АДАС је већ остварио сарадњу са Министарством унутрашњих послова, СБПОК-ом, судовима, тужилаштвима и Управом царине, у виду одржаних радних састанака и едукације, вештачења и стручног сведочења у конкретним случајевима. Само одлучно сузбијање дистрибуције допинг средстава, за шта постоји јасна законска основа, може довести до стварног смањења њихове употребе, не само у врхунском, већ и у рекреативном спорту, где је та опасност и већа, имајући у виду да рекреативни спорт није покривен допинг контролама. У том смислу, од великог би значаја била реализација већ постојеће идеје формирања антидопинг одељења унутар СБПОК-а.

Међународна потврда квалитета и стандарда у раду и деловању АДАС је и сарадња са међународним организацијама. Тако се сарадња одвија са Светском антидопинг агенцијом на реализацији пројекта „Лекари и допинг у спорту: искуства 8 држава балканског региона“. Са Светском кошаркашком федерацијом се ради на четири међународна пројекта. У сарадњи ca УНЕСКО се реализују пројекти антидопинг едукације. Подједнако је важна сарадња са међународним спортским федерацијама. АДАС сарађује са више од десет ИФ, Саветом Европе, Спорт Акордом, као и са другим познатим светским антидопинг организацијама. Потврда доброг рада АДАС на пољу антидопинг борбе, је чињеница да је бивша министарка омладине и спорта у Влади Републике Србије (20072012) Снежана Самарџић Марковић била члан Оснивачког одбора Светске антидопинг агенције од 2009. до 2012. године, а да је сада једна од четири директора Савета Европе, између осталог задужена за спречавање допинга у спорту. 


\section{НАУЧНА ПРОДУКЦИЈА АДАСа -ИСХОД ДЕКАДЕ БОРБЕ ПРОТИВ ДОПИНГА И ЗАШТИТЕ ЗДРАВЉА СПОРТИСТА}

1. Kostic-Vucicevic M., Michalickova D., Dikic N., Stojmenovic T., Andjelkovic M., Nikolic I., Vukasinovic-Vesic M., Malic T. (2017). Food elimination based on immunoglobulin G antibodies improves gastrointestinal discomfort symptoms and sport performance in professional athletes. MED SPORT, 70, 480-94.

2. Curcic Dj., Stojmenovic T., Djukic-Dejanovic S., Dikic N., Vesic-Vukasinovic M. Radivojevic N., Andjelkovic M., Borovcanin M., Djokic G. (2017). Positive Impact of Prescribed Physical Activity on Symptoms of Schizophrenia: Randomized Clinical Trial. PSYCHIATRIA DANUBINA, 29 (4), 459-465.

3. Stankovic I., Michalickova D., Minic R., Kotur-Stevuljevic J., Miljkovic M., Kostic-Vucicevic M., Dikic N., Andjelkovic M., Baralic I., Ivanovic N., Djordjevic B. (2017). Changes in Parameters of Immunological and Oxidative Status in Elite Athletes During Winter (Meeting Abstract). MEDICINE AND SCIENCE IN SPORTS AND EXERCISE, 49 (5), Suppl. 1, 457-457.

4. Stajic A., Andjelkovic M., Dikic N., Rasic J., Vukasinovic-Vesic M., Ivanovic D., Jancic-Stojanovic B. (2017). Determination of higenamine in dietary supplements by UHPLC/MS/MS method. JOURNAL OF PHARMACEUTICAL AND BIOMEDICAL ANALYSIS, 146, 48-52.

5. Ujka K., Bruno R.M., Bastiani L., Bernardi E., Sdringola P., Dikic N., Basyal B., Bhandari S. S., Basnyat B., Cogo A., Pratali L. (2017). Relationship Between Occupational Physical Activity and Subclinical Vascular Damage in Moderate-Altitude Dwellers. HIGH ALTITUDE MEDICINE \& BIOLOGY, 18 (3), 249-257.

6. Andjelkovic M., Bjornsson E., De Bono V., Dikic N., Devue K., Ferlin D., Hanzevacki M., Jonsdottir F., Shakaryan M., Walser Sabine. (2017). The development and appraisal of a tool designed to find patients harmed by falsely labelled, falsified (counterfeit) medicines. BMC HEALTH SERVICES RESEARCH, 17,419 .

7. Banovic M., Nedeljkovic I., Stepanovic J., Giga V., Nedeljkovic M., Petrovic M., Dikic N., Beleslin B. (2017). The value of combined cardiopulmonary end stress-echocardiography testing in discovering latent hfpef in patients with hypertension and normal LV systolic and diastolic function at rest (Meeting Abstract). EUROPEAN JOURNAL OF HEART FAILURE, 19, Suppl. 1, 324-324.

8. Michalickova D., Kostic-Vucicevic M., Vukasinovic-Vesic M., Stojmenovic T., Dikic N., Andjelkovic M., Djordjevic B., Tanaskovic B., Minic R. (2017). L. helveticus Lafti ${ }^{\circledast} 10$ supplementation modulates mucosal and humoral immunity in elite athletes: a randomized double - blinded placebo - controlled trial. Journal of strength and conditioning research / National Strength \& Conditioning Association, 31 (1), 62-70.

1. Дикић Н., Јаковљевић В. (2016). Спортска медицина - уџбеник. Крагујевац: Факултет медицинских наука.

2. Nedeljkovic, I. P., Banovic, M.D., Stepanovic, J. M., Giga, V. L., Djordjevic - Dikic, A., Trifunovic, D. D., Nedeljkovic, M. A., Petrovic, M. Z., Dobric, M., Dikic, N., Zlatar, M., \& Beleslin, B. D. (2016) The combined exercise stress echocardiography and cardiopulmonary exercise test for identification of masked heart failure with preserved ejection fraction in patients with hypertension. EUROPEAN JOURNAL OF PREVENTIVE CARDIOLOGY. 23(1), 71-77.

3. Michalickova D., Minic R., Dikic N., Andjelkovic M., Kostic-Vucicevic M., Stojmenovic T., Nikolic I., Djordjevic B. (2016). Lactobacillus helveticus Lafti ${ }^{\oplus}$ L10 supplementation reduces respiratory infection duration in a cohort of elite athletes: a randomized double - blind placebo - controlled trial. Appl Physiol Nutr Metab., 41(7):782-9.

4. Ujka K., Bruno R.M., Cogo A., Bastiani L., Marinoni A., Bernardi E., Sdringola P., Dikic N., Basyal B., Bhandari S.S., Basnyat B., Bonasoni P., Pratali L. (2016). Black carbon chronic exposure is associated with subclinical cardiovascular damage in Nepalese individuals (Meeting Abstract). EUROPEAN HEART JOURNAL, 37, Suppl. 1, str. 551-551. 
5. Marinkovic D., Minic R., Dikic N., Andjelkovic M., Vukasinovic-Vesic M., Kostic-Vucicevic M., Stoj2016 menovic T., Nikolic I., Djordjevic B. (2016). The Effect of Lactobacillus Helveticus L10 Supplementation on Respiratory Infections and Mucosal Immunity in Elite Athletes (Meeting Abstract). JOURNAL OF CLINICAL GASTROENTEROLOGY, 50, Suppl. 2, S227-S228.

1. Vukasinovic-Vesic M., Andjelkovic M., Stojmenovic T., Dikic N., Kostic M., Curcic Dj. (2015). Sweat rate and fluid intake in young elite basketball players on the FIBA Europe U20 Championship. VOJNOSANITETSKI PREGLED, 72 (12), 1063-1068.

2. Andjelkovic M., Baralic I., Djordjevic B., Kotur-Stevuljevic J., Radivojevic N., Dikic N., RadojevicSkodric S., Stojkovic M. (2015). Hematological and Biochemical Parameters in Elite Soccer Players During a Competitive Half Season. JOURNAL OF MEDICAL BIOCHEMISTRY, 34 (4), 460-466.

2015

3. Baralic, I. R., Andjelkovic, M., Djordjevic, B. I., Dikic, N., Radivojevic, N. J., Suzin-Zivkovic, V., Radojevic-Skodric, S. M., Pejic, S. A. (2015). Effect of Astaxanthin Supplementation on Salivary IgA, Oxidative Stress, and Inflammation in Young Soccer Players. EVIDENCE-BASED COMPLEMENTARY AND ALTERNATIVE MEDICINE, 2015, 783761.

4. Andjelkovic, M., Baralic, I. R., Djordjevic, B. I., Kotur - Stevuljevic, J. M., Radivojevic, N. J., Dikic, N., Radojevic-Skodric, S. M., Stojkovic, M. V. (2015). Hematological and Biochemical Parameters in Elite Soccer Players During a Competitive Half Season. JOURNAL OF MEDICAL BIOCHEMISTRY. 34 (4), 460-466.

1. Дикић Н., Недељковић И. (2014). Стрес тест. Београд: Удружење за спортску кардиологију Србије

2. Анђелковић М., Дикић Н. (2014). Метаболички фитнес. Београд: Удружење за медицину спорта Србије

2014

3. Васлис Клисаурас. (2014). Спортска физиологија. спорта Србије

4. Дикић Н. (2014). Здраво срце за све. Београд: Удружење за медицину спорта Србије

5. Bruno R.M., Ujka K., Cogo A., Bernardi E., Dikic N., Sdringola P., Bashyal B., Bhandari S.S., Basnyat B., Pratali L. Relationship between habitual physical activity and arterial stiffness in Himalayan highaltitude dwellers (Meeting Abstract). EUROPEAN HEART JOURNAL, (2014), 35, 732-732.

1. Dikic N., McNamee M., Guenter H., Samardzic-Markovic S.,Vajgic B. (2013). Sports physicians, ethics and antidoping governance: between assistance and negligence. BRITISH JOURNAL OF SPORTS MEDICINE, 47 (11), 701-704.

2. Baralic I, Djordjevic B, Dikic N, Kotur-Stevuljevic J, Spasic S, Jelic-Ivanovic Z, Radivojevic N, Andjelkovic M, Pejic S. (2013). Effect of astaxanthin supplementation on paraoxonase 1 activities and oxidative stress status in young soccer players. Phytother Res., 27(10), 1536-42.

3. Andjelkovic M., Dikic N., Vukasinovic-Vesic M., Mikovic N., Baralic I., Antic T. (2013).

4. Lifestyle Interventions in Obesity Treatment (Meeting Abstract). ANNALS OF NUTRITION AND METABOLISM, 63, Suppl. 1, 1370-1370.

2013 5. Baralic I., Djordjevic B., Andjelkovic M., Dikic N., Kotur-Stevuljevic J., Dimitrijevic Lj., Antic T., Vukasinovic-Vesic M., Radojevic-Skodric S. (2013). Effects of Astaxanthin Supplementation on Dna Stability and Paraoxonase 1 Activity in Young Soccer Players (Meeting Abstract). ANNALS OF NUTRITION AND METABOLISM, 63, Suppl. 1, 772-772.

6. Djordjevic B., Baralic I., Andjelkovic M., Dikic N., Antic T., Vukasinovic-Vesic M., Blazencic-Mladenovic V., Popovic M., Radojevic-Skodric S., Dietary Intakes and Eating Habits of Elite Athletes in Serbia: Are They Follow the Current Sports Nutrition Standards? (Meeting Abstract). ANNALS OF NUTRITION AND METABOLISM, 63, Suppl. 1, 771-772.

7. Vukasinovic-Vesic M., Dikic N., Baralic I., Antic T., Andjelkovic M., Fluid Consumption of Young Elite Basketball Players (Meeting Abstract). ANNALS OF NUTRITION AND METABOLISM, 63, Suppl. 1, 631-631. 
Дикић Н., Антидопинг агенција - знање, кадрови, иновације..., ФИЗИЧКА КУЛТУРА 2019; 73 (1): $72-88$

1. Djordjevic B., Baralic I, Kotur-Stevuljevic J, Stefanovic A, Ivanisevic J, Radivojevic N, Andjelkovic M,

2012 Dikic N. (2012). Effect of astaxanthin supplementation on muscle damage and oxidative stress markers in elite young soccer players. .J Sports Med Phys Fitness, 52(4), 382-92.

1. Анђелковић М., Дикић Н. (2011). Транс масти. Београд: Удружење за медицину спорта Србије.

2. Dikic N., Samardzic-Markovic S., Mc Namee M. On the Efficacy of WADAs Whereabouts Policy: Between Filing Failures and Missed Tests. DEUTSCHE ZEITSCHRIFT FUR SPORTMEDIZIN, 62 (10), $324-328$.

3. Neskovic A., Dikic N., Jovanovic I. (2011). Ten years of the Echocardiographic Society of Serbia: local achievements with European flavor. EUROPEAN JOURNAL OF ECHOCARDIOGRAPHY, 12 (12), 970-971.

2011 4. Djordjevic-Dikic A., Beleslin B., Stepanovic J., Giga V., Tesic M., Dobric M., Stojkovic S., Nedeljkovic M., Vukcevic V., Dikic N., Petrasinovic Z., Nedeljkovic I., Tomasevic M., Vujisic-Tesic B., Ostojic M. (2011). Prediction of Myocardial Functional Recovery by Noninvasive Evaluation of Basal and Hyperemic Coronary Flow in Patients with Previous Myocardial Infarction. JOURNAL OF THE AMERICAN SOCIETY OF ECHOCARDIOGRAPHY, 24 (5), 573-581.

5. Suzic-Lazic J., Dikic N., Radivojevic N., Mazic S., Radovanovic D., Mitrovic N., Lazic M., Zivanic S., Suzic S. (2011). Dietary supplements and medications in elite sport - polypharmacy or real need? SCANDINAVIAN JOURNAL OF MEDICINE \& SCIENCE IN SPORTS, 21 (2), 260-267.

1. Дикић Н. (2010). Спортска кардиологија - клинички случајеви. Београд: Удружење за спортску кардиологију Србије.

20102. Милинковић 3., Старчевић В., Дикић Н. (2010). Спортска медицина у питањима и одговорима. Београд: Народна књига.

1. Дикић Н. (2009). Практична спортска исхрана. Београд: Удружење за спортску кардиологију Србије.

2009

2. Миџовић М. (2009). Друга стране медаље. Н Дикић (ур.). Београд: Антидопинг агенција Републике Србије

3. Дикић Н. (2009) Бела књига - тимски доктор карика која недостаје. Београд: Удружење за медицину спорта Србије.

1. Живанић С., Дикић Н. (2008). Спортска медицина. Београд: Удружење за медицину спорта Србије.

2. Дикић Н. (2008). Путовање на велике. Београд: Удружење за медицину спорта Срби

1. Дикић Н. (2007). Европске препоруке за учествовање у рекреативном и такмичарском спорту.

2007 Београд: Удружење за медицину спорта Србије.

2. Дикић Н. (2007). 100 питања о допингу. Београд: Антидопинг агенција Републике Србије.

1. Ostojic S., Mazic S., Dikic N. (2006). Profiling in basketball.Physical and physiological characteristics of elite players. JOURNAL OF STRENGTH AND CONDITIONING RESEARCH, 20 (4), 740-744.

2. Дикић Н. (2006). Паралимпијски спорт. Београд: Удружење за медицину спорта Србије

\section{ЗАКЉУЧАК}

Антидопинг агенција Републике Србије је током само једне деценије израсла у једну од најрепрезентативнијих институција спорта и друштва Србије. АДАС је знањем и радом постала не само партнер спортским организацијама у земљи, него и великом броју организација у свету. Стручношћу и непристрасним и одговорним тумачењем Светског антидопинг кодекса, квалитетно и у складу са нормативима, АДАС је ускладила рад са последњим изменама међународних прописа и постала једна од најбољих Агенција у региону. Ипак, и поред јасне међународне препознатљивости, АДАС-у је најважније поверење које је стекла код спортиста у борби за фер и чист спорт. 


\section{Захвалница}

Захваљујем се пре свега мојим првим сарадницима: др Милици Вукашиновић Весић, која је наставила све што сам започео на месту директора АДАС, др Марији Анђелковић која је својом невероватном енергијом и знањем покрила све области антидопинга, Бојану Вајагићу без кога АДАС не би имао интегритет, Бориславу Јаковљевићу и Мирку Стефановићу који се старају да АДАС буде финансијски беспрекорна установа и на крају Милошу Цвјетићанину, који је показао да место систем администратора јесте нешто што треба да има свака модерна установа. Захваљујем се проф. др Ненаду Ђурђевићу на успешно написаном Закону о спречавању допинга у спорту, као и свим члановима Управног одбора, Антидопинг одбора и ТУЕ одбора. Захваљујем се и свим допинг контролорима који нису само прошли кроз АДАС, већ уградили део себе у протеклој деценији. Такође се подједнако захваљујем др Наталији Милчић Матић и њеном тиму који је некад и у неповољним условима спроводио допинг контроле коња и урадио много на добробити животиња. Наше истраживање и писање не би било могуће без подршке проф. др Владимира Јаковљевића, проф. др Брижите Ђорђевић и проф. др Слободана Живанића. Коначно се захваљујемо свима који су нас подржали током протекле деценије, између осталих и проф. др Браниславу Јевтићу који не само да нас је увек разумео, већ и битно утицао на решавање проблема суплементације у спорту. 